\title{
ArcheoSciences
}

Revue d'archéométrie

$40 \mid 2016$

Varia

\section{The marble of O Incio (Galicia, Spain): Quarries and first archaeometric characterisation of a material used since roman times}

Le marbre d'O Incio (Galice, Espagne) : carrières et première caractérisation archéométrique d'un matériau employé depuis l'époque romaine

\section{Anna Gutiérrez Garcia-M., Hernando Royo Plumed, Silvia} González Soutelo, Marie-Claire Savin, Pilar Lapuente and Rémy Chapoulie

\section{OpenEdition \\ Journals}

\section{Electronic version}

URL: https://journals.openedition.org/archeosciences/4783

DOI: 10.4000/archeosciences.4783

ISBN: 978-2-7535-5384-2

ISSN: 2104-3728

\section{Publisher}

Presses universitaires de Rennes

\section{Printed version}

Date of publication: 30 December 2016

Number of pages: 103-177

ISBN: 978-2-7535-5382-8

ISSN: 1960-1360

Electronic reference

Anna Gutiérrez Garcia-M., Hernando Royo Plumed, Silvia González Soutelo, Marie-Claire Savin, Pilar Lapuente and Rémy Chapoulie, "The marble of O Incio (Galicia, Spain): Quarries and first

archaeometric characterisation of a material used since roman times", ArcheoSciences [Online], 40 I 2016, Online since 30 December 2018, connection on 23 February 2022. URL: http://

journals.openedition.org/archeosciences/4783 ; DOI: https://doi.org/10.4000/archeosciences.4783 


\title{
The marble of O Incio (Galicia, Spain): Quarries and First Archaeometric Characterisation of a Material Used since Roman Times
}

\author{
Le marbre d'O Incio (Galice, Espagne) : carrières et première caractérisation \\ archéométrique d'un matériau employé depuis l'époque romaine
}

\author{
Anna Gutiérrez Garcia-M. ${ }^{a}$, Hernando Royo PlumeD ${ }^{\mathrm{b}}$, \\ Silvia González Soutelo ${ }^{c}$, Marie-Claire Savin $^{a}$, Pilar Lapuente ${ }^{d}$ \\ et Rémy Chapoulie ${ }^{a}$
}

\begin{abstract}
In spite of the great leap forward experienced in our understanding of the use of marble and other ornamental stones in Roman Spain, provenance studies are still quite uncommon in some territories of the Iberian Peninsula. This was the case of the northwesternmost part (modern Galicia), where no significant work had been done until now. Within the framework of an interdisciplinary study, a significant number of objects studied did not match with the main well-known Classical marbles but seemed to have been produced with a local stone known as $\mathrm{O}$ Incio marble, which had never been yet archaeometrically analysed. Therefore, the quarries near the small village of O Incio were located and sampled, and a multi-method approach combining polarized-light microscopy, cathodoluminescence, $\mathrm{X}$-ray powder diffraction and stable $\mathrm{C}$ and $\mathrm{O}$ isotope analysis as well as spectrophotometry was applied to characterize the different outcropping marble varieties as the first and basic step to correctly differentiate them from other Iberian and foreign marbles with similar macroscopic features.

Résumé : De grandes avancées ont été réalisées récemment concernant l'emploi des marbres et des autres roches ornementales dans l'Espagne romaine. Cependant, certains territoires de la péninsule Ibérique ne font l'objet que de rares études de provenance. Ceci était le cas du nord-ouest (actuelle Galice), où aucun travail n'avait été mené jusqu'à présent. Dans le cadre d'une étude interdisciplinaire, un nombre important d'objets ne correspondait pas aux principaux marbres classiques, mais semblaient avoir été mis en cuvre à partir d'un matériau local connu sous le nom de marbre d'O Incio qui n'avait jamais fait l'objet d'une caractérisation archéométrique. C'est ainsi que les carrières avoisinant le petit village d'O Incio ont été localisées et échantillonnées. Une approche multi-méthode combinant analyse pétrographique, cathodoluminescence, diffraction de rayons $X$, analyse des isotopes stables de $C$ et $O$ et spectrophotométrie a été menée afin de caractériser les différentes variétés de marbre. Cela constitue la première étape fondamentale pour les différencier d'autres marbres ibériques et étrangers macroscopiquement similaires.
\end{abstract}

Keywords: O Incio, quarries, marble, petrography, cathodoluminescence, geochemistry, spectrophotometry.

Mots clés: O Incio, carrières, marbre, pétrographie, cathodoluminescence, géochimie, spectrophotométrie.

\footnotetext{
a Institut de Recherche sur les ArchéoMATériaux (IRAMAT), Centre de Recherche en Physique Appliquée à l'Archéologie (CRP2A), UMR 5060 CNRS, Université Bordeaux Montaigne, France (anna.gutierrez@u-bordeaux-montaigne.fr) (marie-claire.savin@u-bordeaux-montaigne.fr)(remy.chapoulie@ubordeaux-montaigne.fr)

${ }^{b}$ Institut Català d'Arqueologia Clàssica (ICAC), Tarragona, Spain. (hroyo@icac.cat)

'Grupo de Estudos de Arqueoloxía, Antigüidade e Territorio (GEAAT), Universidade de Vigo, Spain (silviagonzalez@uviqo.es)

' Petrology and Geochemistry, Earth Sciences Department, Zaragoza University, Spain (plapuent@unizar.es)
} 


\section{INTRODUCTION}

\section{Marble use in Roman Gallaecia (NW Spain): an unaddressed question}

Marble was one of the noble material most widely used in the Roman world. Since late Republican times and in particular during the Imperial Age, the use of decorative marbles became fashionable in Rome. Marble was especially sought-after to be used in architecture and the plastic arts and, in opposition to other stones, its use was often linked with self-representation of the display of status, either from an individual, a family or even a social/political group (such a town). All sort of marbles were widely employed to produce a large number of objects, from sculptures, inscriptions, sarcophagi or even furniture, as well as to decorate all sorts of buildings and public spaces. Among them, white marbles had a prominent place. The western provinces of the Roman Empire were not an exception and soon after their conquest and control by Rome, they followed the example set by the Urbs and adopted the use of marble, even if it meant to import it from other areas (especially marble-rich eastern territories such as Greece and Asia Minor, Carrara in Italy or central North-Africa) or to put into use the up to then unexploited local natural resources.

During the last decades, the understanding of the use of marble in Roman Spain has leapt forward. The studies undertaken by the research teams of the Autonomous University of Barcelona and the Catalan Institute of Catalan Archaeology on the northeast (modern Catalonia), the University of Zaragoza on the Ebro valley, the University of Murcia on the ancient conventus Carthaginensis, the University of Seville on the ancient Baetica province, the National Museum of Roman Art and the University of Zaragoza on the southern part of Roman Lusitania, the UNED on the north-central meseta and the works on specific marble assemblages ${ }^{1}$ have provided a more complete picture of the use of marbles and decorative stones in Hispania. As a result of this, we not only now have a better understanding of the volume, use and areas of arrival of foreign marbles, such as, for example, the marble of Carrara (Gutiérrez Garcia-M. \& Rodà, 2012), but also of the importance and scope of use of some high-quality Spanish stones that were also used in wider than merely local areas².

1. See for example, those on the Roman villae of Carranque, Noheda, Las Pizarras or Els Munts (García-Entero \& Vidal, 2007, 2012; Gutiérrez Garcia-M. et al., 2009; Otińa, 2002, 2003; Pérez et al., 2012; Valero et al., 2015).

2. Most of these teams' works have been presented in the Proceedings of several scientific meetings in Spain (Beltrán \& Nogales, 2009; García-
Nevertheless, there are still significant gaps regarding some other Iberian territories, especially the Atlantic regions. Among them, the northwesternmost part (modern Galicia ${ }^{3}$ ) (Figure 1), where no significant work had been done on this subject. Even though the number of objects made in marble found there is somewhat smaller compared with other regions of Spain, they are nonetheless a very interesting evidence of the economic mechanisms of the society that produced or consumed them. Besides, the lack of in-depth studies in this region hindered our capacity not only to understand all the historical aspects related to the economic structure and social complexity developed in Gallaecia, but also to complete the global picture marble use in Roman Spain.

\section{The "Marmora Galicia" project}

As part of a broader research aimed to enlarge our knowledge of stone exploitation in Roman times ${ }^{4}$, we set up an interdisciplinary study of the marble objects found in this region as a first and essential step to establish what marbles were used in this territory, to what purpose, where did they come from, how did they arrived to their place of use and the dating of their exploitation or presence in this region, so far away from the Mediterranean and from the most common marble trade networks. It combines archaeometric analysis with purely archaeological and artistic aspects to get a global comprehension of the objects per se and the agents involved in their production and use. The comparison of mineralogical-petrographic characteristics, cathodoluminescence and C-O stable isotope data, using the same methodology on an extensive marble reference collection of both Iberian and Classical marbles sources ${ }^{5}$, is the basis to identify the provenance of the raw material employed for these objects. The stylistic approach is the only way to propose a date (even if approximate) for those pieces found out of stratigraphic context or reused in later buildings. On the

Entero, 2012) as well as the latest ASMOSIA Conferences (Gutiérrez Garcia-M. et al., 2012; Pensabene \& Gasparini, 2015; ASMOSIA XI, in preparation) and some monographic works (Àlvarez et al., 2009a, 2009b).

3. Which corresponds approximately to ancient Gallaecia.

4. The "Marmora Galicia" project is carried out thanks to the collaboration between the GEAAT of the University of Vigo, the ICAC and the IRAMAT-CRP2A within the framework of the projects "La explotación y comercio de los recursos naturales en el n. este de la Hispania romana: lapis, metalla, aqua (HAR2011-25011)", "Officinae Lapidariae Tarraconenses. Canteras, talleres y producciones artísticas en piedra de la provincial Tarraconense (HAR2015-65319-P)" and "Lapides et marmora Hispaniae: exploitation, utilisation et distribution des pierres de l'Hispanie romaine " of the LaScArBx.

5. Available at the collections of the ICAC, the LEMLA (Laboratory for the Study of Lithic Materials in Antiquity) of the Autonomous University of Barcelona, and Zaragoza University, as well as with the reference databases available from several quarrying areas operating in Roman times. 
Figure 1: Map showing the location of the marble objects found in Galicia, quarries under study, and the main Roman towns and roads of ancient Gallaecia (map: S. González Soutelo). Figure 1 : Localisation des objets en marbre trouvés en Galice, les carrières étudiées ainsi que les principales villes et routes romaines de la Gallaecia (carte : S. González Soutelo).

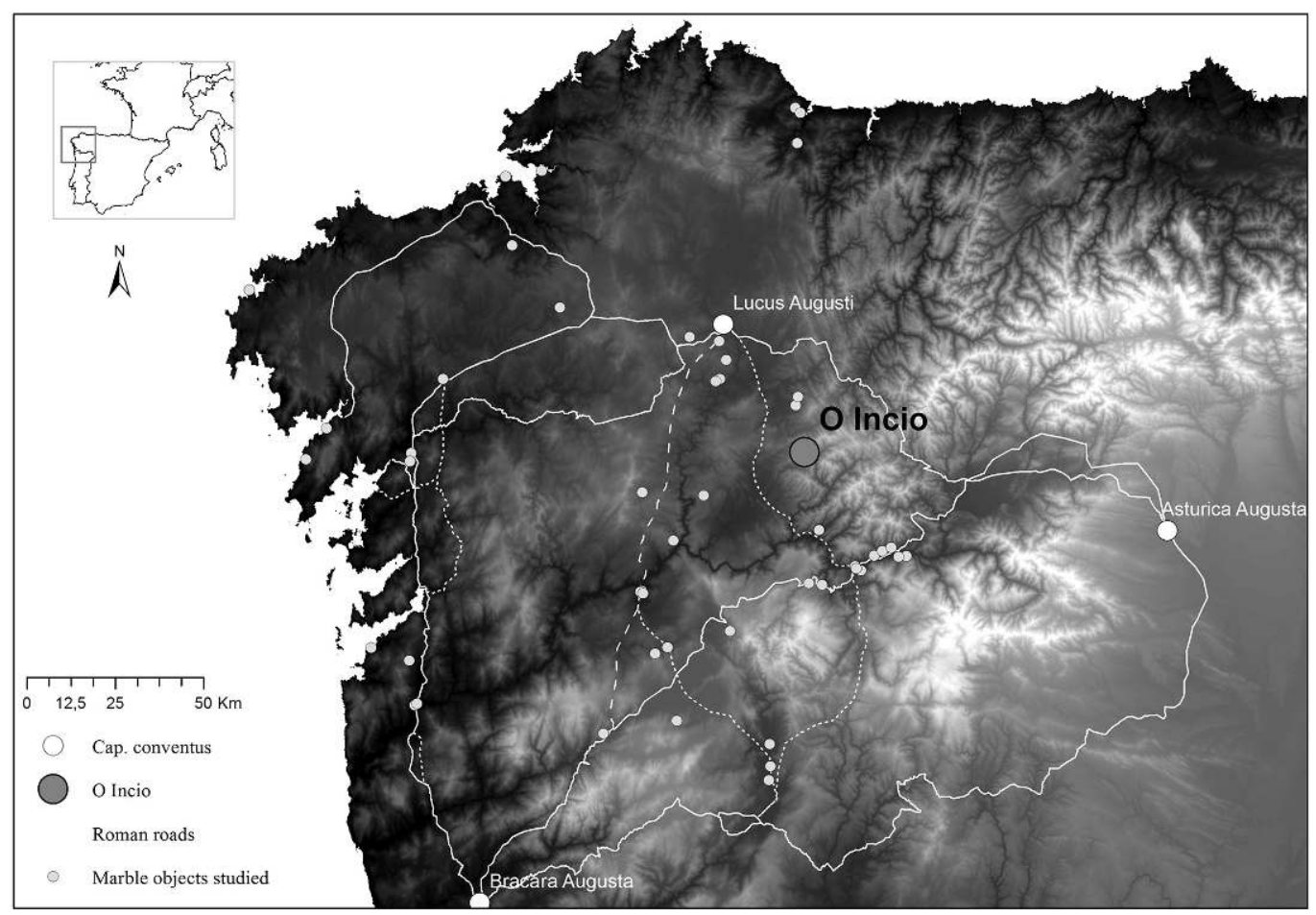

other hand, it allows identifying possible workshops, and the correlation between their specific features and the use of a particular raw material can help to understand whether they were local artisans or if they arrived from somewhere else.

Consequently, all the information available on marble pieces dating from Roman and Late Roman times found in Galicia has been compiled and introduced in a database. So far, we have traced the existence of ca. 120 Roman white or white/grey marble objects, most of which lack of any stratigraphic context since they were unearthed by chance during the last century or reused in pre-Romanesque and Romanesque churches. This compilation includes very different sorts of evidences, from architectural elements - capitals or columns -, which are the big majority, to fragments of sculptures or carvings, inscriptions, altars and even some sarcophagi. All of them were considered to obtain a picture as global as possible of the range of marbles used in Antiquity in this region and their intended purposes. The macroscopic inspection of most of these objects enabled a first recording of the main traits of the marbles employed ${ }^{6}$. Soon enough it became clear that local marbles played a significant role on the marble consumption in this territory, as some of these

6. At last, we were authorized to get a sample from twenty-nine pieces. Subsequently, fifteen of them showing various granulometries and macroscopic traits were selected as the first to be archaeometrically analysed; the results of these study is partly presented in Gutiérrez Garcia-M. et al., in press. objects presented very particular features that did not match the features of the main well-known Classical marbles neither those of the southern Spanish ones?

To locate the source and to archaeometrically characterize these local marbles became a main requisite, for none of them had yet been object of scientific studies. In fact, the marble outcropping in the small village of $\mathrm{O}$ Incio $^{8}$ (Figure 1) has been traditionally considered as the only one being exploited on the NW of Spain in Roman times but this statement had no scientific base as it was merely founded on its very characteristic visual (usually greyish white with dark grey veins). Therefore, this was the first one to be addressed.

\section{Brief historical context of $O$ Incio and its surroundings}

The area of O Incio, located on the south of the Lugo province, has a rich archaeological heritage, among which stand

7. That is, the marbles from Almadén de la Plata, Estremoz, Macael and Mijas (Lapuente et al., 2000, 2002, 2014; Beltrán \& Loza Azuaga, 2003; Ontiveros et al., 2012; Taylor 2015; among others).

8. Although in some works it has been referred by the Spanish name "Incio" (see Canto, 1977-78; Braemer, 1986; Cisneros, 1988), we will henceforth use the Galician and official form, i.e. preceded with the article "O". The Galician nomenclature will we also applied to other place or geographical names in this paper. 
out some megalithic and pre-Roman sites ${ }^{9}$. Conversely, little data exists about the Roman period in the region apart from the necropolis of O Medorro de S. Pedro, located about $200 \mathrm{~m}$ of the Romanesque church of Hospital and partially excavated in 1968, or the several mentions to the use of the marble presumably from $\mathrm{O}$ Incio to carve $5^{\text {th }}$ c. A.D. Late Roman-early Christian elements found in the parish of A Ermida (municipality of Quiroga), among which the well-known Crismon (Rodriguez Colmenero, 1993: 464). Similarly, the discovery of some art pieces, among which a relief with a crucifixion motif carved on limestone found during the above-mentioned archaeological excavation $s^{10}$, seems to point to the existence of a religious building prior to the construction of the $12^{\text {th }} \mathrm{c}$. church of Hospital ${ }^{11}$. This church, which nowadays continues to be the parish church, is extremely interesting since it was completely built with marble ashlars. The uniformity of these ashlars and of all the other architectural elements shows that the exceptional use of this material was not the result of reusing previously existing elements but from the exploitation of the nearby outcrops, thus proving the existence of active quarries in early medieval times.

\section{THE QUARRIES}

The identification of outcrops providing local marble that could have been exploited in Antiquity is crucial. On the one hand, obtaining samples directly from the outcrops is essential to produce the reference core required to undertake provenance studies and to ensure that they are representative of the whole outcrop. On the other hand, it is the only way to explore the possible existence of a marble industry in Roman Gallaecia and its extent.

Despite granite is the main stone resource exploited in Galicia, the existence of small marble occurrences have been known. Among them, the ones located near the small village $O$ Incio had been generally regarded as being employed since Antiquity ${ }^{12}$. They are located on the eastern part of O Incio's territory, on the foothills of the Sierra do Courel Mountains ${ }^{13}$.

9. The later are known in Galicia as "castros" (Iron Age hillforts).

10. This piece was found under the pavement of the Romanesque church apse and was dated from the $6^{\text {th }}$ c. A.D. (Delgado Gomez,1987: 53-54).

11. A written document dating from the 1003 and kept in the monastery of Samos mentions the existence of a monastery dedicated to $S$. Felix of Incio even before the $9^{\text {th }}$ century A.D. (Maximino Arias, 1983: 14).

12. See Canto (1977-78: 180), Braemer (1986: 310, fig. 4) and Cisneros (1988: 59-60).

13. Also known as Sierra del Caurel (Spanish version of the Galician name).
Nevertheless, there is virtually no information on their exploitation in ancient or medieval times, and only very occasionally they are mentioned by late $18^{\text {th }}$ to mid- $20^{\text {th }} \mathrm{c}$. scholars (Cornide, 1783:57; Madoz, 1847: T. IX, 428; Amor Melián, 1936). In spite of that, quarrying was an important industry at $\mathrm{O}$ Incio until the 1960s and the several extraction points recognised during the field survey demonstrate that this material was exploited in several areas.

These outcrops are part of the few ones belonging to the Lower Cambrian Cándana Group, defined by Lotze (1958) which has been mapped as limestones and dolostones (layer 2, in Figure 2) at Sierra do Courel. The Cándana Group represents a thick sequence (up to more than $2000 \mathrm{~m}$ ) of siliciclastic and carbonate materials, mostly deposited under shallow marine conditions, and has been related to an Ovetian age by biostratigraphic studies (Liñán et al., 1993, 2002). During the Variscan Orogeny, the Early Paleozoic lithostratigraphic units were affected by different tectono-metamorphic events, and consequently marbles were developed from those Cambrian carbonate rocks. Similar sequences occur not only in the NW of Spain, but also in other terrains of the Iberian Massif, where marbles with different qualities underwent complex structural evolution. In Galicia, and in particular in the region under consideration, $\mathrm{O}$ Incio marbles are structurally located in the known as West Asturian-Leonese Zone (WALZ) (Lotze, 1945), just on its southern limit, in contact to the northern boundary of the Galician-Castilian Zone, represented by the Caurel-Truchas domain (Pérez-Estaún et al., 1990) which is the lateral continuation of the Mondoñedo nappe. The WALZ defines a distinctive arcuate band of a continuous succession from Upper Proterozoic to Devonian materials, with regular folding structures and reduced extension of granitic massifs. The metamorphism ranges from greenschist to amphibolite facies, with a progressive increase towards the western part of the zone where the Variscan granitic rocks become abundant (Martinez Catalán, 1990). In addition, in this area the amount of strain is very small as is the regional metamorphism (Aller et al., 1987), which is essentially synkinematic (Capdevilla, 1969) with medium pressure characteristics.

Although the written sources mentioned three quarries in the territory of $\mathrm{O}$ Incio, only two of them, situated near Pacios and Hospital respectively, have been located and studied

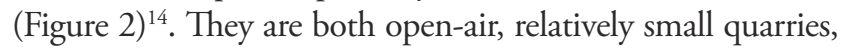
yet they provide a highly variable material, which made all the more important its archaeometric characterisation.

14. The third one, near Dompiñor, is probably within a currently private property that could not be accessed. The geographical proximity between Dompiñor and Pacios quarry $(\mathrm{ca} .500 \mathrm{~m})$ strongly suggests that the same marble varieties are to be found there. 
Figure 2: (See colour plate XII) Map showing the location of the quarries around $\mathrm{O}$ Incio and detail of the geological map (IGME, sheet 156, IGME 2002) with indication of the two quarries. Figure 2: (Voir planche couleur XII) Situation des carrières aux environs d'O Incio et détail de la carte géologique (IGME, feuille 156, IGME 2002) avec indication des deux carrières.
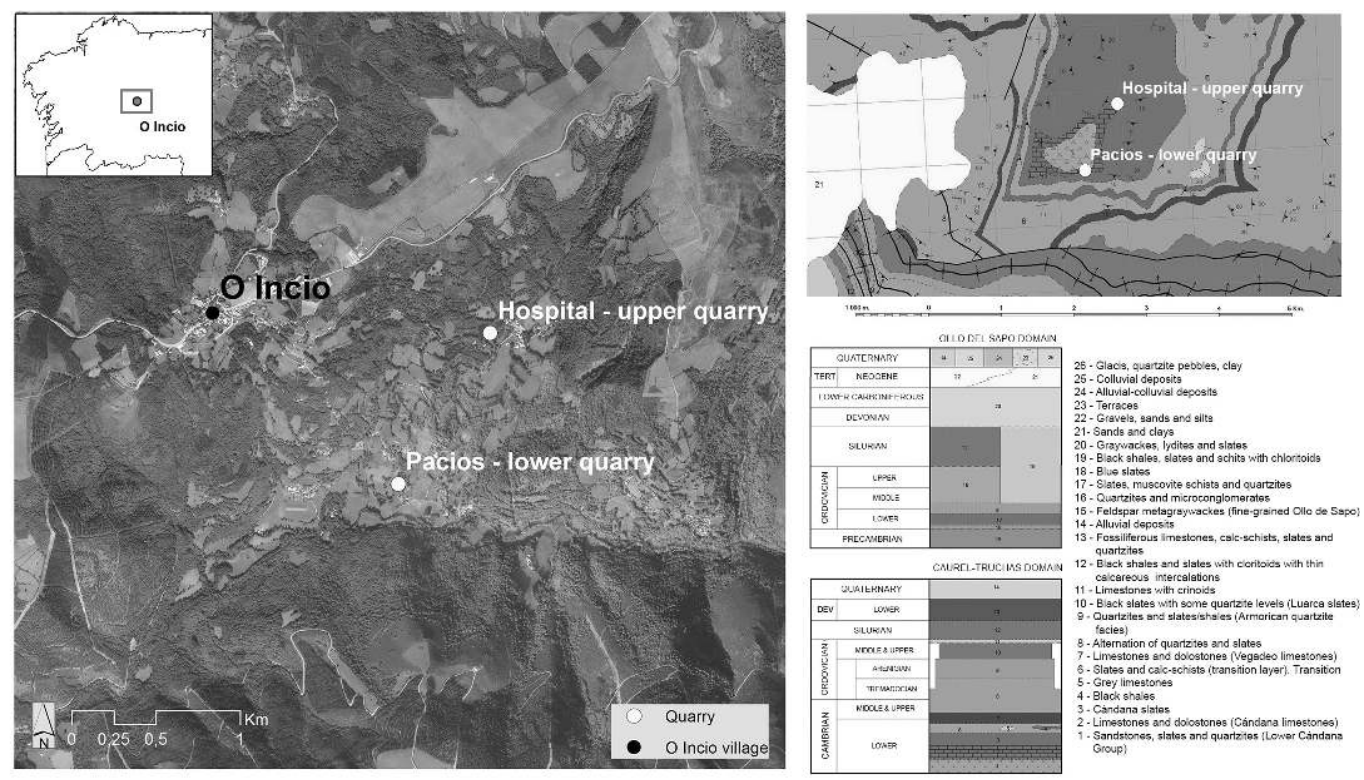

Pacios quarry, also known as "lower quarry" due to its position $^{15}$ at the foothills near where the Rego de Pereira stream joints the Cabe river, is locally considered the oldest one. It consist on a ca. $4 \mathrm{~m}$ high quarry front running in an approximately N-S direction for about $50 \mathrm{~m}$ and opened on the left bank of the mentioned stream. Most of the extraction traces currently visible are the result of very recent extraction ${ }^{16}$ and they follow an intermediate wearingdown exploitation strategy. However, on the upper part of the site there are some small, scattered, mostly orthogonal cuts forming rough benches (Bessac, 2003: 26) (Figure 3). Although they are very shallow and almost completely covered by soil, their location on the upper part of the front and the occasional traces of human-made trenches as well as the orthogonal angles that cannot be due to natural erosion or fracture strongly point to an earlier extraction phase. The homogeneity and massive layers of this outcrop allow extracting rather large masses of stone from the bedrock. Some big blocks still stand abandoned opposite to the lineal front, together with three heaps of piled up, smaller boulders and debris. Although there are no rough-hewn or unfinished elements, it is clear that this quarry provided big enough blocks to be used to carve architectural pieces such as the ones identified on the archaeological record or in the earlymedieval churches. Moreover, its location on the foothills

15. Coordinates ETRS89 UTM 29 635.228/4.722.948 or 42³8'64”N7०21’25”W

16. As the demonstrated by the two small huts - one still standing and a collapsed one - with several equipment to cut the bedrock with helicoidal wire and the few traces of drilling on the fronts; during this last period the main products were aggregates and gravel for road building. and facing the river, the natural route out of the valley into the Sil river, one of the largest of Galicia, is an ideal location for the potential transport of this quarry's marble towards other regions.

Hospital quarry, also known as "upper quarry" or "A Pedreira", is located further up of the same hill, at about $300 \mathrm{~m}$ west from the Romanesque marble church of Hospital $^{17}$. It is an open-air quarry consisting of two fronts: an almost semi-circular one that after a small change of direction, continues further south for ca. $11 \mathrm{~m}^{18}$; and a roughly crescent-shaped, $6 \mathrm{~m}$ long one. This configuration points to an intermediate extraction strategy possibly combining the wearing down and in terraces quarry-types (Bessac, 2003: 26) They are facing a path going towards the nearby hamlet of Hospital and the road that follows the same route; between these two, marble boulders and quarrying debris are piled up in an elongated ca. $18 \mathrm{~m}$ long $4 \mathrm{~m}$ high heap (Figure 4). As Pacios quarry, it was in use until very recently ${ }^{19}$ and a small, partly collapsed hut on the southern limit of the quarry testifies to this period of extraction. The ca. $10 \mathrm{~m}$ high, vertical fronts are most likely the result of the last exploitation although no traces of hydraulic drilling or other modern extraction techniques have been found, but they could still exist hidden under the dense vegetation that covers most of the fronts. The visible evidences consist on smooth, vertical, massive surfaces and a few, scattered artifi-

17. Coordinates ETRS89 UTM $29635.757 / 4.723 .84$ or $42^{\circ} 39^{\prime} 18^{\prime \prime}$ $\mathrm{N}-7^{\circ} 20^{\prime} 37^{\prime \prime} \mathrm{W}$.

18. Until it is lost under a soil-made ramp that allows access to the upper part of the quarry.

19. The 1970s, according to some of the locals. 


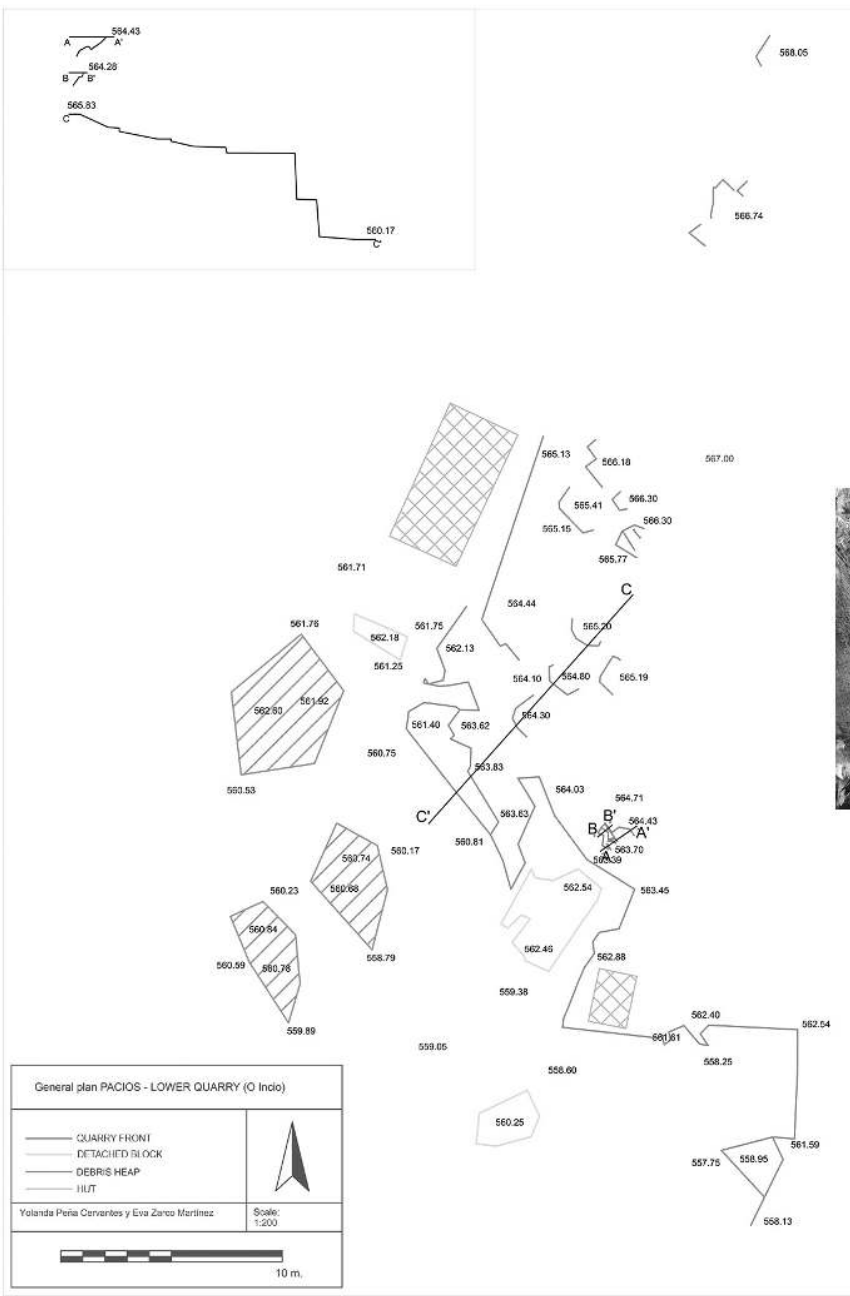

cial cuts forming $90^{\circ}$ angles and horizontal surfaces, are the result of pre-industrial extraction techniques. Nevertheless, its proximity to the $12^{\text {th }} \mathrm{c}$. church, where a large part of the blocks match the lighter varieties of marble cropping out at this quarry, and the fact the locals remember the finding of already cut blocks while the quarry was operational seems to confirm an earlier period of extraction, probably in the Middle Ages. Likewise, the possibility of the medieval builders profiting of an already opened quarry on the best quality marble outcrops of the area, cannot be ruled out.

\section{Materials AND ANALYTICAL METHOdS}

In the summer of 2012 a field survey was conducted and despite the dense vegetation that nowadays covers both quarries, they were systematically sampled. A total number of fourteen samples covering the whole range of outcropping varieties were taken mostly from the quarry fronts, both ver- tically and horizontally in relation to the visible outcrops, or from the debris pits identified either just in front or in their immediate surroundings, when getting enough sample of a specific variety directly from the bedrock was not possible. The number of samples is approximately proportional to the extension of the respective quarry front as well as the variability of the material.

According to their visual appearance (colour and presence of irregularities) and grain size, these samples have been visually classified into three lithotypes (Figure 5):

- O Incio-1 is a fine-grained, white marble with thin orange veins and occasional centimetric light grey bands. The orange veins, which are related with iron minerals, are usually more well-defined than the dimmer grey bands but in both cases they tend to be very fine and subparallel. This marble is slightly translucent.

-O Incio-2 is a banded, fine-grained marble where white and grey bands of varying tone or shade alternate almost constantly. These bands can have very different patterns, 
Figure 4: (See colour plate XIV) Hospital quarry: general plan (left), view of the northern limit of the quarry (right, above) and details of the extraction fronts, currently almost completely covered by vegetation (right, center and below) (plan: Y. Peńa Cervantes and E. Zarco Martínez; photos: A. Gutiérrez Garcia-M.).

Figure 4: (Voir planche couleur XIV) Carrière d'Hospital: plan général (à gauche), vue de la limite nord de la carrière (en haut à droite) et détails du front d'extraction, aujourd'hui presque entièrement couverts de végétation à droite, au centre et en bas) (plan: Y. Peña Cervantes et E. Zarco Martínez; photos: A. Gutiérrez Garcia-M.).

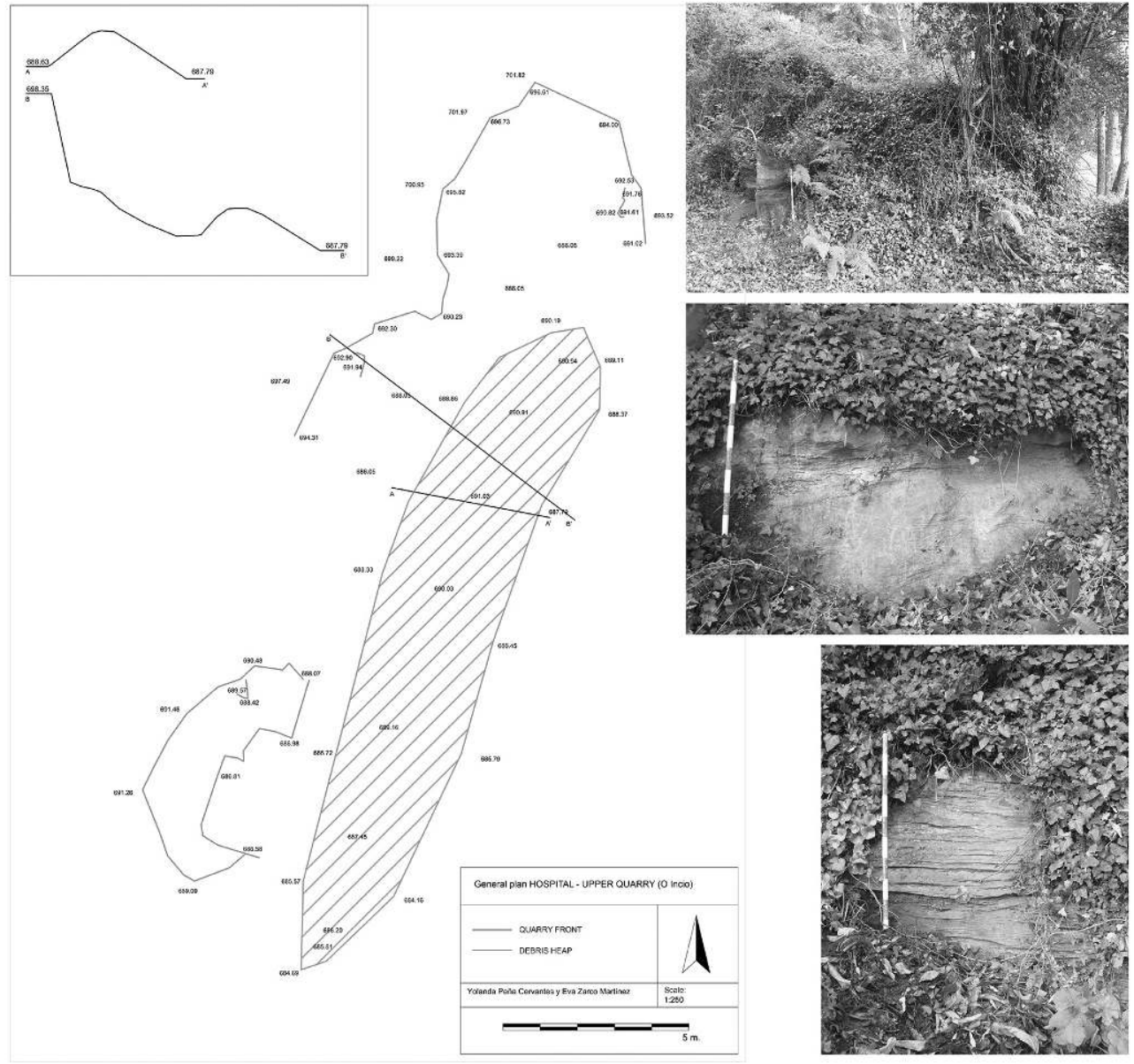

from being completely parallel, straight, very thin and continuous (to the point of becoming a lamination) to being larger, undulated and less well-defined. The result is, hence, a wide variety of macroscopic combinations. Some poorlycrystalline areas can be observed as well as a faint translucence when the white bands are predominant.

- O Incio-3 is a greyish marble of a general darker shade than the previous ones with grey bands of different tones (from medium grey to almost black ones) and occasional lighter coloured, thin veins. As in O Incio-2, these can be parallel but usually present some undulation.

$\mathrm{O}$ Incio-2 is the most common variety, and can be found both in Pacios and Hospital quarries, while O Incio-1 mainly occurs at the upper layers of Hospital quarry fronts. The darker varieties (O Incio-3) are mainly present at Pacios quarry.

A well-established multi-method approach ${ }^{20}$ combining different analytical techniques has been applied to establish

20. It has been discussed in detail elsewhere, see for example, Lazzarini et al., 1980; Barbin et al., 1992; Gorgoni et al., 2002; Lapuente et al., 2000, 2014; Attanasio et al., 2006. the characteristics of each lithotype. X-ray powder diffraction (XRD) was used to detect dolomite and calcite, as well as possible accessory minerals. Optical microscopy (OM) was used to examine the mineralogy, fabric, texture, Grain Boundary Shape (GBS) and Maximum Grain Size (MGS). These parameters have a particular diagnostic significance for marble discrimination (Weiss, 1954; Herz, 1955; Moens et al., 1988; Capedri \& Venturelli, 2004), especially combined with other analytical results such as from cathodoluminescence (CL) and the Ratio Mass Spectrometry of the Carbon and Oxygen Stable Isotopes (IRMS). The CL characteristics of carbonates are known to be mainly related to their chemical impurities (Chapoulie et al., 2016). The colour of calcite and dolomite under CL microscopy can be described as a combination of yellow, orange and red. Dolomite usually exhibits a red luminescence (Casenave et al., 2003), while calcite is typically yellow-orange, but it occasionally shows a dull blue luminescence as well (Boggs \& Krinsley, 2006). This colour variability is attributed to the absence or presence of multiple emission bands and to 

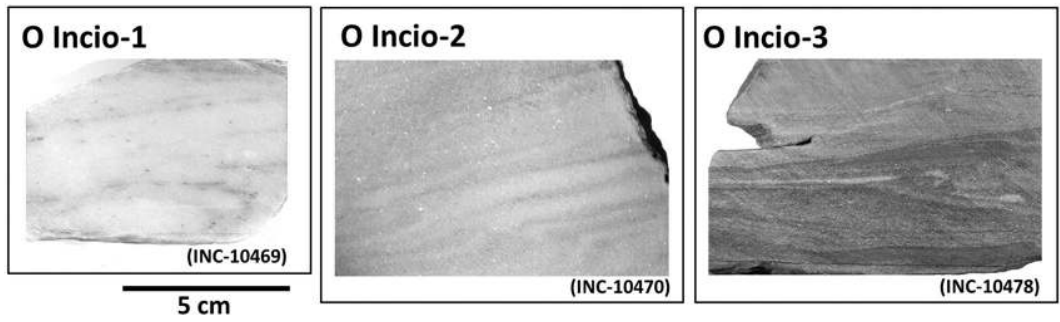

Figure 5: (See colour plate XIV) Macroscopic appearance of the three $\mathrm{O}$ Incio marble varieties. Figure 5: (Voir planche couleur XIV) Aspect macroscopique des trois variétés de marbre d'O Incio. different amounts of activator elements and to point defects of the carbonate group, such as $\mathrm{Mn}^{2+}$ and quenching ions, such as $\mathrm{Ni}^{2+}$ and $\mathrm{Co}^{2+}$ (Machel, 1985; Machel et al. 1991; Habermann et al., 1998; Barbin et al., 1989, 1992; Blanc, 1994, 1999; Casenave et al., 2003). Despite the overlapping and some controversial results in discriminating, Oxygen and Carbon stable isotopes remain the most used parameters for provenance marble (Attanasio et al., 2006). The presence of the typical odour of sulphur that some marbles emit when scratched or broken up has been also considered. Following Attanasio (2003: 99), it has been used as a simple categorical variable (absence/presence) due to its importance as this purely qualitative parameter can be especially significant in the case of banded or veining marbles.

Spectrophotometry was applied to objectify the visual parameters of this marble. This experimental method can contribute in cases of problematic discrimination of marbles with similar macroscopic aspect being used in Antiquity ${ }^{21}$, as already tested on marbles from some Pyrenean quarries (Royo et al., in press). A portable Minolta CM-2600d spectrophotometer associated with SpectraMagic NX 2.5 software was used to evaluate three different points of each sample's colour; in the bicolour lithotypes both white and grey were separately considered. The surface measured is a window of $\varnothing 3 \mathrm{~mm}$ and all measurements were repeated 3 times at each point. The results are thus the mean of 9 values. The measurements were carried out only on flat surface after sawing. The measuring conditions were: illuminant D65, $1931\left(10^{\circ}\right)$ CIE standard colorimetric observer. Colour measurements were expressed using the CIE-L*a*b* colour system ${ }^{22}$ organised around three axes, $\mathrm{L}^{*}, \mathrm{a}^{*}$ and $\mathrm{b}^{*}$, forming a sphere where $\mathrm{L}^{*}$ axis represents lightness or luminosity ${ }^{23}$, which varies from 0 black to 100 white, $\mathrm{a}^{*}$ the red-green coordinate and $\mathrm{b}^{*}$ the yellow-blue one. Among the 3 measurable phenomenon responsible for the colour

21. O Incio marble is especially similar to some banded white/grey fine-grained marbles from the Estremoz Anticlinal (Portugal) and from the central Pyrenean regions of Ossau and Louvie-Souviron (France).

22. CIE-L*a*b* colour system has been chosen because it better represents human perception to colour than other encoding systems like CIE$\mathrm{XYZ}$ or CIE-RGB.

23. Thus overcoming the limitations from mere visual perception and vocabulary ("white", "white-grey", "grey”, etc.). perception -specular component, diffuse reflection from the surface and diffuse reflection from the inside, the two former ones depend on the surface state but the sum of them stays constant. In $\mathrm{SCI}^{24}$ mode, all of these components are measured, while in $\mathrm{SCE}^{25}$ mode, most of the specular component is excluded. All measurements were performed in these two modes to observe the effect of surface finish.

Eleven samples, representative of each lithotype, were selected and cut into thin sections for petrographic investigation. OM and CL were basically undertaken with a Nikon Eclipse 50iPOL microscope with a coupled CL8200 MK5-1 cold equipment. The electron energy was 15-20 kV and the beam current was operated at 250-300 $\mu \mathrm{A}$. The observed luminescent colours, intensity and distribution in each sample were recorded with an automatic digital Nikon CoolPix 5400 camera. The CL images taken were automatically controlled $(29 \mathrm{~mm}$ focal length, $\mathrm{f} / 4.6$ aperture, $1 \mathrm{~s}$ exposure, ISO-200) to obtain comparative images of their $\mathrm{CL}$ intensity. CL can produce slightly different results according to the diverse instrumentation used and the related setting (Lapuente $\&$ Royo, in press). To make comparisons with a certain degree of approximation, a CL image of white Carrara marble is provided, which exhibits what we consider a dark orange faint intensity to be used as a standard reference pattern.

Few grams of this same selection of eleven samples have been crushed and finely grounded in an agate mortar and homogenized for XRD and isotopic analysis. The XRD spectra were recorded using a diffractometer Bruker D8 Advance in Bragg-Bretano geometry $(\mathrm{CuK} \alpha$ target tube $\mathrm{X}$-ray source, operating at $40 \mathrm{kV}$ and $40 \mathrm{~mA}$ ). The angular range $(2 \theta)$ was explored by a goniometer scanning from $3^{\circ}$ to $60^{\circ}$ at a step size of $0.02^{\circ}$ and a counting time of 1 second per step. The Isotopic Ratio Mass Spectrometry of ${ }^{13} \mathrm{C}$ and ${ }^{18} \mathrm{O}$ were determined with a Finnigan Gasbench II equipment ${ }^{26}$. A Finnigan MAT Kiel II automatic preparation device was previously used $(15 \mathrm{mg}$ ) for phosphoric acid digestion at $72{ }^{\circ} \mathrm{C}$ and $\mathrm{CO}_{2}$ purification. The results were

24. SCI: Specular Component Included.

25. SCE: Specular Component Excluded.

26. At the Instituto di Geologia Ambientale e Geoingegneria, Consiglio Nazionale delle Ricerche (IGAG-CNR), Roma (Italy). 
expressed in terms of usual delta notation $\left(\delta^{13} \mathrm{C}\right.$ and $\left.\delta^{18} \mathrm{O}\right)$ in \%o relative to the international reference standard $\mathrm{PDB}$ (Pee Dee Belemnite).

\section{Results}

\section{Colorimetric values}

In agreement with their visual variation, running from white to grey/dark grey, $\mathrm{O}$ Incio marble presents CIE$\mathrm{L}^{*} \mathrm{a}^{*} \mathrm{~b}^{*}$ colour space coordinates ranging from $\mathrm{L}^{*}=49.69, \mathrm{a}^{*}$ $=-1.07$ and $b^{*}=-3.61$ to $L^{*}=82.13, a^{*}=1.13$ and $b^{*}=9.27$ (in SCI mode) (Figure 6) and the relative difference with the values in SCE mode are minimal (on average: $0.256 \pm 0.12$ for $L^{*},-0.02 \pm 0.01$ for $a^{*}$ and $0 \pm 0.02$ for $\left.b^{*}\right)$. Therefore, the surface finish of the samples does not have a significant effect on the colour values obtained ${ }^{27}$.

Taking into account the $\mathrm{L}^{*}$ values in SCI mode, O Incio1 lithotype is well defined between 75.89 to 81.95 ( $\sigma$ $=79.57 \pm 2.42)$ and $\mathbf{O}$ Incio-3 lithotype is also clearly separated with $L^{*}$ values between 49.69 to $68.79(\sigma=59.25 \pm 7.59)$. In contrast, $\mathbf{O}$ Incio-2 presents a large range of $\mathrm{L}^{*}$ values from 58.07 to $82.13(\sigma=72.96 \pm 7.81)$, as could be expected from the usual combination of white and grey bands.
Indeed, the white parts of $\mathrm{O}$ Incio-2 samples (points 19 and 4) overlap with $\mathrm{O}$ Incio-1, and some grey parts of $\mathrm{O}$ Incio-2 group (points 20,15 and 5) are in the same ranges than the grey $\left(67<\mathrm{L}^{*}<70\right)$ and dark grey parts $\left(\mathrm{L}^{*}<60\right)$ of O Incio-3.

Moreover, the results also give chromatic indications. In the $\mathrm{a}^{*}, \mathrm{~b}^{*}$ diagram, O Incio-1 samples as well as the white part of an $\mathrm{O}$ Incio-2 sample (point 10) are the only ones showing a yellow component $\left(\mathrm{a}^{*}: \sigma=-0.22 \pm 0.78 ; \mathrm{b}^{*}\right.$ : $\sigma=3.72 \pm 3.34)$. O Incio-2 samples have predominantly small green and blue components $\left(a^{*}: \sigma=-0.80 \pm 0.17 b^{*}\right.$ : $\sigma=-1.22 \pm 1.23)$ with the exception of the grey bands of samples INC-10337 and INC-10479 (points 5 and 20, respectively) where, similarly to the $\mathrm{O}$ Incio-3 samples, the blue component prevails $\left(a^{*}: \sigma=-0.93 \pm 0.13 ; b^{*}\right.$ : $\sigma=-2.97 \pm 0.56)$.

\section{Mineralogical-petrographic features}

The results of the mineralogical-petrographic examination together with the CL features and isotopic values are summarized in Table 1.

The samples belonging to $\mathbf{O}$ Incio-1 show an isotropic mostly heteroblastic fabric in mosaic, sometimes lineated, or banded. The grains present predominantly straight to slightly curved boundaries although in some cases they can also be

\begin{tabular}{lllllll} 
id & Sample & Lithotype & PVD & \multicolumn{2}{l}{ SCI mode } & \\
\cline { 5 - 7 } & & & & $\boldsymbol{L}^{*}(\mathbf{D} 65)$ & $\boldsymbol{a}^{*}(\mathbf{D} 65)$ & $\boldsymbol{b}^{*}(\mathbf{D 6 5})$ \\
\hline 1 & INC-10335 & O Incio-3 & grey & 54,47 & $-0,98$ & $-3,14$ \\
2 & INC-10335 & O Incio-3 & dark grey & 49,69 & $-0,91$ & $-3,47$ \\
3 & INC-10336 & O Incio-1 & white & 78,29 & $-0,65$ & 2,72 \\
4 & INC-10337 & O Incio-2 & white & 79,17 & $-0,9$ & 2,14 \\
5 & INC-10337 & O Incio-2 & grey & 58,07 & $-0,88$ & $-2,85$ \\
6 & INC-10469 & O Incio-1 & white-grey & 75,89 & $-0,82$ & 0,14 \\
7 & INC-10470 & O Incio-1 & white & 82,43 & 0,25 & 6,1 \\
8 & INC-10470 & O Incio-1 & white & 79,69 & $-0,31$ & 1,96 \\
9 & INC-10471 & O Incio-2 & white-grey & 75,53 & $-0,83$ & $-1,49$ \\
10 & INC-10472 & O Incio-2 & white & 82,13 & $-0,51$ & 0,87 \\
11 & INC-10472 & O Incio-2 & grey & 74,11 & $-0,98$ & $-1,45$ \\
12 & INC-10473 & O Incio-3 & grey & 68,79 & $-0,98$ & $-2,43$ \\
13 & INC-10474 & O Incio-2 & white & 75,54 & $-0,83$ & $-0,62$ \\
14 & INC-10475 & O Incio-1 & white & 81,95 & 1,13 & 9,27 \\
15 & INC-10476 & O Incio-2 & white-grey & 67,52 & $-0,59$ & $-0,59$ \\
16 & INC-10477 & O Incio-3 & grey & 56,45 & $-0,69$ & $-2,21$ \\
17 & INC-10478 & O Incio-3 & grey & 67,85 & $-1,07$ & $-2,98$ \\
18 & INC-10478 & O Incio-3 & dark grey & 58,24 & $-0,95$ & $-3,61$ \\
19 & INC-10479 & O Incio-2 & white & 81,11 & $-0,8$ & $-0,77$ \\
20 & INC-10479 & O Incio-2 & grey & 69,66 & $-1,01$ & $-2,82$ \\
\hline & & & & & &
\end{tabular}
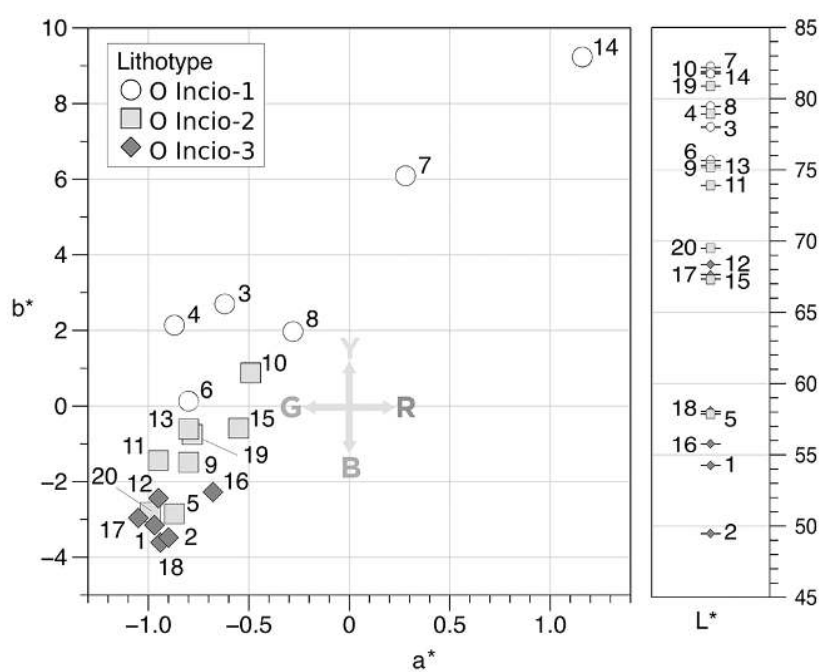

Figure 6: Table with the preliminary visual description (PVD) and CIE-L*a*b*colorimetric values with D65 illuminant in SCI mode (left); $\mathrm{a}^{*}, \mathrm{~b}^{*}$ chromaticity diagram, with the $\mathrm{L}^{*}$ axis plotted separately for clarity (right). G, R, Y and B letters represent respectively Green, Red, Yellow and Blue directions.

Figure 6: Table présentant les descriptions visuelles préliminaires (PVD) ainsi que les coordonnées $L^{*}$, $a^{*}$ et $b^{*}$ du système colorimétrique CIE$L^{*} a^{*} b^{*}$ obtenues avec l'illuminant D65 en mode SCI (à gauche). Diagramme binaire des coordonnées chromatiques $a^{*}$ et $b^{*}$, l'axe $L^{*}$ est représenté à part pour plus de lisibilité (à droite); les lettres $G, R, Y$ et $B$ désignent les composantes vertes ( $G:$ Green), rouge (R:Red), jaune ( $Y:$ Yellow) et bleue (B : Blue).

27. Thus, only the SCI values will be given henceforth. 


\begin{tabular}{|c|c|c|c|c|c|c|c|c|c|c|c|c|c|c|c|}
\hline $\begin{array}{l}\text { Litho- } \\
\text { type }\end{array}$ & Sample & $\begin{array}{c}\text { Main } \\
\text { Minerals }\end{array}$ & $\begin{array}{l}\text { Accesory } \\
\text { Minerals }\end{array}$ & Texture & Fabric & $\frac{\text { MGS }}{(\mathrm{mm})}$ & GBS & Stress & Odour & $\begin{array}{l}\text { CL Distribu- } \\
\text { tion }\end{array}$ & CL Intensity & CL Hue & $\begin{array}{l}\text { CL Irre- } \\
\text { gularities }\end{array}$ & $\begin{array}{l}\delta^{13} \mathrm{C} \\
(\% 0)\end{array}$ & $\begin{array}{l}\delta^{18} \mathrm{O} \\
(\% 0)\end{array}$ \\
\hline 1 & INC-10469 & Cal & $\begin{array}{c}\mathrm{Phl} / \mathrm{Mc} / \mathrm{Qtz} / \\
\mathrm{Op} / \mathrm{Ch}^{*}\end{array}$ & $\begin{array}{l}\text { Hetero- } \\
\text { blastic }\end{array}$ & Banded & 1.2 & $\begin{array}{l}\text { Straight/ } \\
\text { Curved/ } \\
\text { Sutured }\end{array}$ & No & - & $\begin{array}{l}\text { Heteroge- } \\
\text { neous }\end{array}$ & Very faint & Brown & No & 1.0 & -14.9 \\
\hline 1 & INC-10475 & $\begin{array}{c}\mathrm{Cal} / \\
((\mathrm{Dol}))^{*}\end{array}$ & $\begin{array}{c}\mathrm{Phl} / \mathrm{Mc} / \mathrm{Qtz} / \\
\mathrm{Op} / \mathrm{Ch}^{*}\end{array}$ & $\begin{array}{l}\text { Hetero- } \\
\text { blastic }\end{array}$ & $\begin{array}{c}\text { Mosaic/ } \\
\text { (Lineated) }\end{array}$ & 1.0 & $\begin{array}{l}\text { Straight/ } \\
\text { Curved }\end{array}$ & No & - & $\begin{array}{l}\text { Heteroge- } \\
\text { neous }\end{array}$ & Very faint & Brown & No & 1.7 & -11.0 \\
\hline 2 & INC- 10470 & Cal & $\begin{array}{c}\mathrm{Mc} / \mathrm{Qtz} / \mathrm{Ph} \mathrm{l} / \\
\mathrm{Op}\end{array}$ & $\begin{array}{l}\text { Hetero- } \\
\text { blastic }\end{array}$ & $\begin{array}{l}\text { Mosaic/ } \\
\text { Lineated }\end{array}$ & 1.6 & $\begin{array}{l}\text { Straight/ } \\
\text { Curved/ } \\
\text { Sutured }\end{array}$ & No & - & $\begin{array}{l}\text { Heteroge- } \\
\text { neous }\end{array}$ & Medium & Orange & No & 0.7 & -16.0 \\
\hline 2 & INC-10471 & Cal & $\mathrm{Mc} / \mathrm{Qtz} / \mathrm{Op}$ & $\begin{array}{l}\text { Homeo- } \\
\text { blastic }\end{array}$ & $\begin{array}{c}\text { Mosaic/ } \\
\text { (Lineated) }\end{array}$ & 1.2 & $\begin{array}{l}\text { Straight/ } \\
\text { Curved }\end{array}$ & No & - & $\begin{array}{l}\text { Heteroge- } \\
\text { neous }\end{array}$ & Faint & $\begin{array}{c}\text { Dark } \\
\text { orange }\end{array}$ & No & 0.6 & -14.3 \\
\hline 2 & INC-10472 & Cal & $\mathrm{Mc} / \mathrm{Qtz} / \mathrm{Op}$ & $\begin{array}{l}\text { Hetero- } \\
\text { blastic }\end{array}$ & $\begin{array}{l}\text { Mosaic/ } \\
\text { Lineated }\end{array}$ & 1.6 & $\begin{array}{l}\text { Curved/ } \\
\text { Sutured }\end{array}$ & No & - & $\begin{array}{l}\text { Heteroge- } \\
\text { neous }\end{array}$ & Medium & Orange & No & 2.3 & -10.4 \\
\hline 2 & INC-10474 & Cal & $\mathrm{Mc} / \mathrm{Qtz} / \mathrm{Op}$ & $\begin{array}{l}\text { Hetero- } \\
\text { blastic }\end{array}$ & $\begin{array}{l}\text { Mosaic/ } \\
\text { Lineated }\end{array}$ & 1.6 & $\begin{array}{l}\text { Straight/ } \\
\text { Curved }\end{array}$ & No & $(+)$ & $\begin{array}{l}\text { Heteroge- } \\
\text { neous }\end{array}$ & Medium & Orange & No & 0.8 & -15.9 \\
\hline 3 & INC-10473 & $\mathrm{Cal} / \mathrm{Dol}$ & $\mathrm{Qtz} / \mathrm{Mc} / \mathrm{Op}$ & $\begin{array}{l}\text { Hetero- } \\
\text { blastic }\end{array}$ & $\begin{array}{c}\text { Lineated/ } \\
\text { Banded }\end{array}$ & 1.0 & $\begin{array}{l}\text { Straight/ } \\
\text { Curved }\end{array}$ & No & - & $\begin{array}{l}\text { Heteroge- } \\
\text { neous }\end{array}$ & Medium & Orange & $\begin{array}{c}\text { Subordi- } \\
\text { nate Min. } \\
\text { [Dol] }\end{array}$ & 1.3 & -15.7 \\
\hline 3 & INC-10476 & $\mathrm{Cal} /(\mathrm{Dol})$ & $\mathrm{Qtz} / \mathrm{Mc} / \mathrm{Op}$ & $\begin{array}{l}\text { Hetero- } \\
\text { blastic }\end{array}$ & $\begin{array}{c}\text { Lineated/ } \\
\text { Banded }\end{array}$ & 1.1 & $\begin{array}{l}\text { Straight/ } \\
\text { Curved }\end{array}$ & No & - & $\begin{array}{c}\text { Heteroge- } \\
\text { neous }\end{array}$ & Faint & $\begin{array}{c}\text { Dark } \\
\text { orange }\end{array}$ & $\begin{array}{c}\text { Subordi- } \\
\text { nate Min. } \\
\text { [Dol] }\end{array}$ & 1.9 & -12.9 \\
\hline 3 & INC-10477 & $\mathrm{Dol} / \mathrm{Cal}$ & $\begin{array}{c}\mathrm{Qtz} / \mathrm{Mc} / \mathrm{Ph} \mathrm{Ph} \\
\mathrm{Op}\end{array}$ & $\begin{array}{l}\text { Hetero- } \\
\text { blastic }\end{array}$ & $\begin{array}{c}\text { Lineated/ } \\
\text { Bandeed }\end{array}$ & 0.8 & $\begin{array}{l}\text { Curved/ } \\
\text { Embayed }\end{array}$ & No & - & $\begin{array}{l}\text { Heteroge- } \\
\text { neous }\end{array}$ & Faint & $\begin{array}{c}\text { Dark } \\
\text { orange }\end{array}$ & $\begin{array}{c}\text { Subordi- } \\
\text { nate Min. } \\
\text { [Dol] }\end{array}$ & 1.8 & -15.1 \\
\hline 3 & INC-10478 & $\mathrm{Cal} / \mathrm{Dol}$ & $\begin{array}{c}\mathrm{Qtz} / \mathrm{Mc} / \mathrm{Phl} / \\
\mathrm{Op}\end{array}$ & $\begin{array}{l}\text { Hetero- } \\
\text { blastic }\end{array}$ & $\begin{array}{c}\text { Lineated/ } \\
\text { Banded }\end{array}$ & 1.1 & $\begin{array}{l}\text { Curved/ } \\
\text { Embayed }\end{array}$ & No & - & $\begin{array}{l}\text { Heteroge- } \\
\text { neous }\end{array}$ & Faint & $\begin{array}{c}\text { Dark } \\
\text { orange }\end{array}$ & $\begin{array}{c}\text { Subordi- } \\
\text { nate Min. } \\
\text { [Dol] }\end{array}$ & 1.1 & -16.0 \\
\hline 3 & INC-10479 & $\mathrm{Cal} /(\mathrm{Dol})$ & $\begin{array}{c}\mathrm{Qtz} / \mathrm{Mc} / \mathrm{Phl} / \\
\mathrm{Op}\end{array}$ & $\begin{array}{l}\text { Hetero- } \\
\text { blastic }\end{array}$ & $\begin{array}{c}\text { Lineated/ } \\
\text { Banded }\end{array}$ & 1.1 & $\begin{array}{l}\text { Curved/ } \\
\text { Embayed }\end{array}$ & No & - & $\begin{array}{l}\text { Heteroge- } \\
\text { neous }\end{array}$ & Medium & Orange & $\begin{array}{c}\text { Subordi- } \\
\text { nate Min. } \\
\text { [Dol] }\end{array}$ & -1.2 & -16.4 \\
\hline
\end{tabular}

Table 1: Minero-petrographical and cathodoluminescence features, and isotopic signature of the marble samples from O Incio. (): subordinate or occasionally; (()): very rare. *: detected by XRD. Cal: calcite. Dol: dolomite. Qtz: quartz. Phl: phlogopite. Mc: white mica. Op: opaque minerals. Ch: chlorite. + : presence. - : absence.

Tableau 1: Caractéristiques pétrographiques, de cathdoluminescence et les signatures isotopiques des échantillons de marbre d'O Incio. () : occasionnel. (O) : très rare. ${ }^{*}$ : détecté en DRX. Cal: calcite. Dol: dolomite. Qtz:quartz. Phl: phlogopite. Mc: mica blanc. Op: minéraux opaques. Ch: chlorite. + : présence. - : absence.

sutured. Some underdeveloped tabular thick twins can be observed and there are no signs of intracrystalline deformation. MGS ranges from 1.0 to $1.2 \mathrm{~mm}$. Mineralogically, it is a pure calcite marble and accessory phlogopite and white mica flakes are always present, either associated to the finest-grained calcite bands, or dispersed between the coarser grains. Other accessory minerals are quartz and opaques as well as chlorite and very scarce dolomite, the former only inferred by XRD analysis. CL in these samples is brown and heterogeneous (irregularly marked with intracrystalline patches), with a very faint intensity (Figure 7).

Similarly, O Incio-2 type samples consist of a mosaic of mostly heteroblastic calcite grains with straight to slightly curved boundaries, only occasionally gently layered and with sutured boundaries. In this case, however, the fabric in mosaic is sometimes also lineated. The MGS is homoge- neous (from 1.2 to $1.6 \mathrm{~mm}$ ). XRD has not detected dolomite, thus we have to consider it a pure calcitic marble ${ }^{28}$. In this case, however, no traces of chlorite have been found. Some tabular thick twins can be observed on the crystals, but as in O Incio-1, there are no signs of intracrystalline deformation. Mica flakes are always the main accessory mineral, followed by quartz and opaques. Phlogopite has only been occasionally detected (INC-10470). The CL distribution of this lithotype is heterogeneous, but with more evident intracrystalline patches (as in sample INC-10470) and a brighter luminescence concentrated along the grain borders (especially clear in sample INC-10472) than in the previous lithotype. There is a predominance of orange with

28. Nevertheless, the occasional presence of dolomite cannot be ruled as it is usually associated to the grey bands (see O Incio-3); further analysis are currently in process to verify this point. 
a medium intensity luminescence yet one of the samples (INC-10471) shows a dark orange faint CL. The accessory minerals are non- or low-luminescent (Figure 7).

As for $\mathbf{O}$ Incio-3 lithotype, the first main difference is the higher content of dolomite, which seems to be strongly related to the darker grey areas or bands. The microtexture is also heteroblastic. In this case, however, the marble fabric is strongly banded, characterized by the variances in grain-size and composition (entirely calcite bands alternate with calc-dolomite bands), and lineated. The MGS ranges from 1.0 to $1.1 \mathrm{~mm}$ and the boundaries between the grains are predominantly curved or straight, but some embayed borders have been observed. Again, white mica, quartz, opaques and phologopite appear as accessories, although there is slightly more quartz than in O Incio-1 and $\mathrm{O}$ Incio-2. CL is heterogeneous in all the samples, but it ranges from dark orange faint intensity to orange medium intensity in the calcite bands and it is dark red on the other ones due to higher content of calcium magnesium carbonate (dolomite) (Figure 7).

\section{Isotopic values}

O Incio marble isotopic values range from -16.4 to $-10.4 \% 0\left(\delta^{18} \mathrm{O}\right)$ and from -1.2 to $2.3 \% 0\left(\delta^{13} \mathrm{C}\right)$ (Table 1$)$. Considering the number of samples analysed and that the $-1.2 \%$ carbon value of INC- 10479 is the only negative in the group, and could therefore be considered an outlier, the plotted field encloses only the area defined by each sample to avoid distortion ${ }^{29}$ (Figure 8). Despite the limited number of samples, they provide a quite distinctive isotopic values. They are clearly set apart from the rest of the fine-grained white and white/grey Classical marbles from the central and eastern territories of the Roman Empire (i.e. Carrara marble from Italy, Pentelic and Paros-1 marbles from Greece, or Iscehisar - ancient Dokimeion - and Göktepe marbles from inland Asia Minor) as well as from the most widely distributed fine-grained Peninsular marble known so far, which outcrops in the Estremoz Anticline, in southern Portugal, and which can also appear with dark grey bands (Lapuente et al., in press).

\section{Conclusions}

The definition of the archaeometric features characterising the marble from $\mathrm{O}$ Incio is an important addition to the field of marble provenance. It provides the necessary

29. The results of currently on-going analysis will allow confirming or completing it.
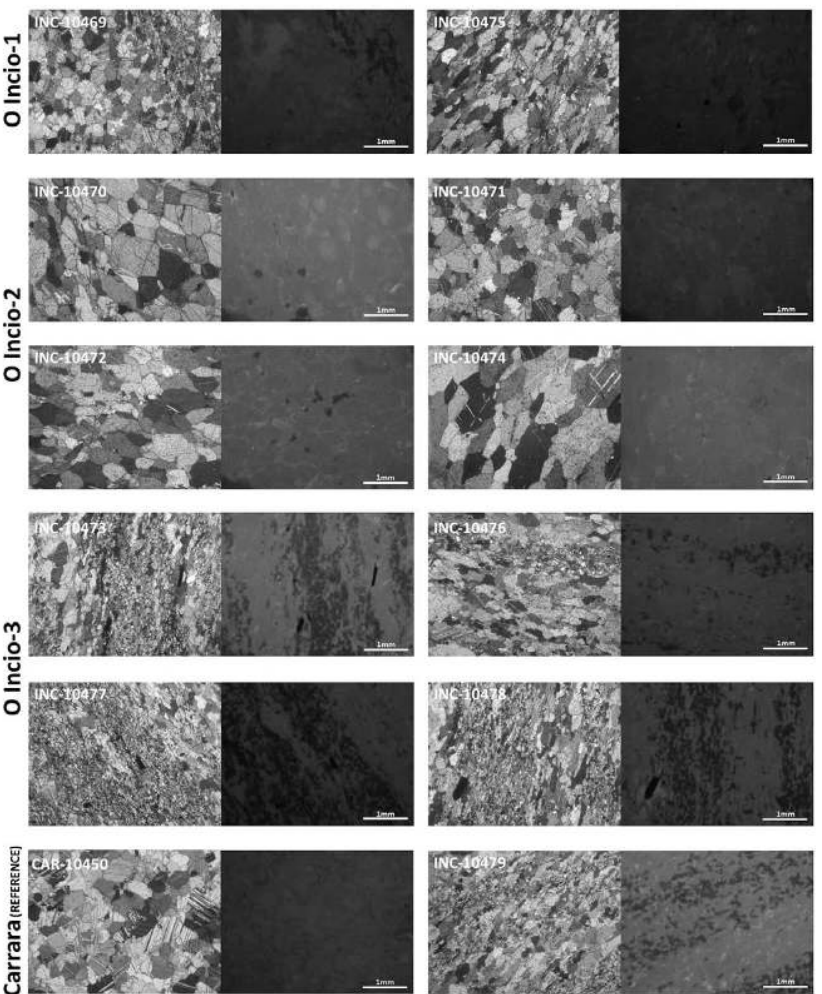

Figure 7: (See colour plate XV) Photomicrographs under analyzer (left) and cathodomicrofacies (right) of O Incio marble reference samples, with a typical Carrara marble as standard reference for the CL (photos: H. Royo Plumed).

Figure 7 : (Voir planche couleur XV) Photomicrographies en lumière polarisée analysée (à gauche) et cathodomicrofacies (à droite) des échantillons de référence d'O Incio, avec un marbre de Carrara typique comme référence normalisée pour la CL (photos: H. Royo Plumed).

reference upon which to compare the marbles used for an array of sculptures, inscriptions and architectural elements found in the archaeological record or reused in post-Roman buildings. The high variability of the petrographic and CL facies is compensated with a quite distinctive isotopic signature, thus enhancing the power of discrimination even at this initial level of the research. This is particularly interesting as the presence of ancient objects made of non-Galician marbles sometimes presenting macroscopic features overlapping those of $\mathrm{O}$ Incio marble, such as Estremoz Anticline marble from southern Portugal, has been already spotted in the NW of Spain (Vidal \& Garcia-Entero, 2015). Similarly, the existence of French Pyrenean marbles with analogous features and widely distributed through some northern regions of Hispania ${ }^{30}$ adds to the complexity of

30. Especially in the central and north-eastern parts (Royo, 2016), but for which the arrival to the North-West through the Atlantic coast cannot be ruled out. 

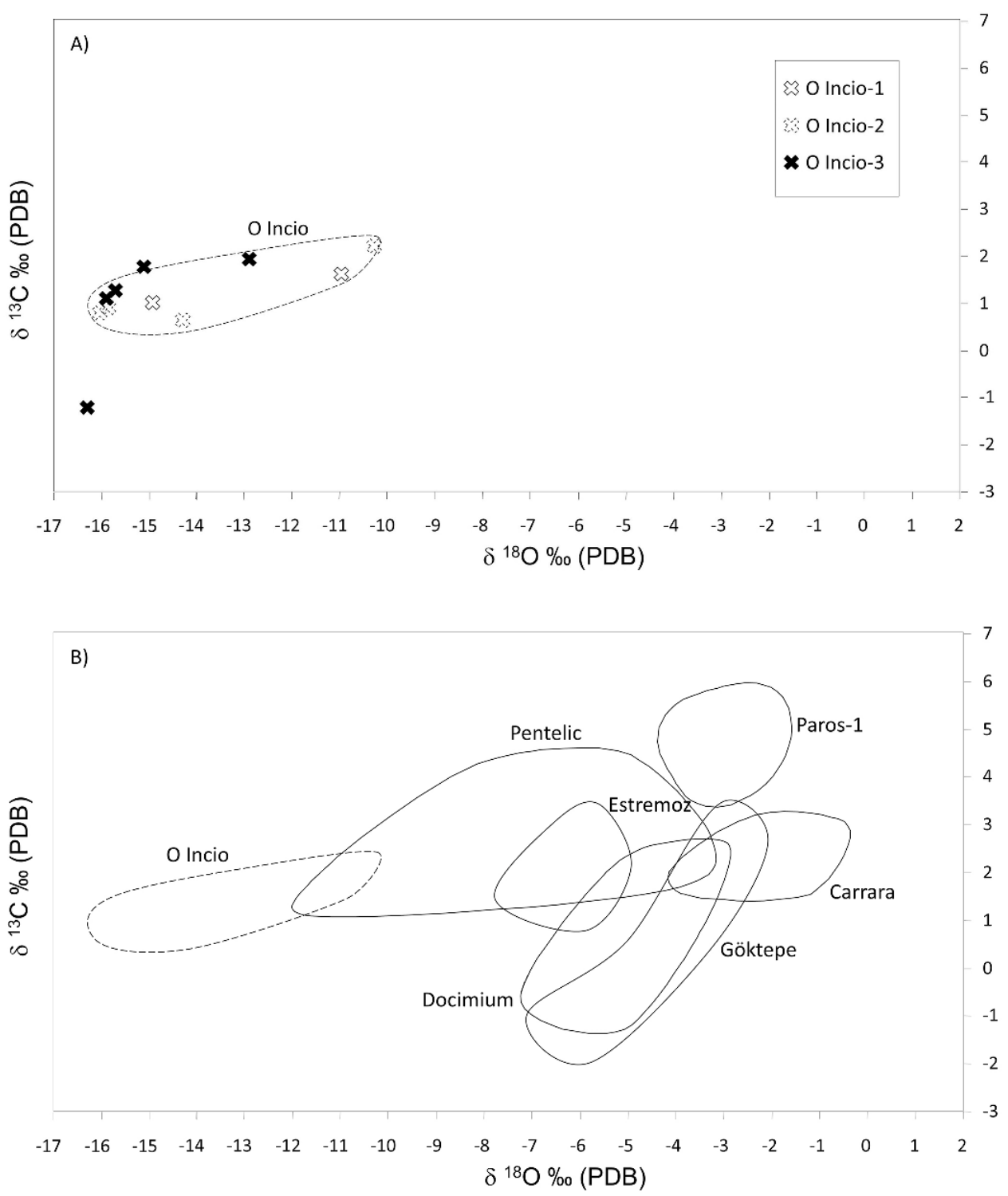

Figure 8: A) Stable isotope diagram showing the signature data of $\mathrm{O}$ Incio marble samples and its proposed isotopic field. B) O Incio isotopic field compared to fields of Classical and Hispanic marbles with similar features (fine-grained, average MGS < $2 \mathrm{~mm}$ ) (Gorgoni et al., 2002; Lapuente et al., 2014 for white marbles from the Estremoz Anticline; Attanasio et al., 2015, for data of Götepe).

Figure 8 : A) Diagramme représentatif des isotopes stables montrant les rapports obtenus sur les échantillons de marbre d'O Incio et le champ isotopique proposé. B) champ isotopique de O Incio comparé aux champs isotopiques des marbres classiques et hispaniques présentant des caractéristiques similaires (à grain fins, taille maximale des grains < $2 \mathrm{~mm}$ ) (Gorgoni et al., 2002; Lapuente et al., 2014 pour les marbres blancs de l'anticlinal d'Estremoz; Attanasio et al., 2015, pour les données de Göktepe). marble provenance identification in Galicia. In this respect, the results of the accurate colorimetric characterisation of O Incio marble allows us to transcend the stage of a simple visual observation as first step towards a new possible nondestructive method to increase the discrimination potential among these white/grey marbles so difficult to distinguish to the naked eye ${ }^{31}$. All in all, the addition of O Incio marble to our reference collection will finally enable to correctly

31. Colorimetric analysis has been recently applied to Estremoz grey and greyish banded marbles (Lapuente et al., in press) and to Pyrenean marbles, with some promising results on the differentiation between SaintBéat and Prokonnesos marbles (Lapuente et al., 2005; Royo, 2016; Royo et al., in press). Nevertheless, we are still in a very early phase and more experiences (including a larger set of quarry samples of O Incio marble as well as archaeological materials) must be tested to assess its reliability. provenance a large set of marble objects. The historical consequences of the use of either local or imported marbles are indeed significant, both in terms of marble arrival at Roman Galicia and of grasping the scale and reach of some non-Galician marbles.

This characterisation has been put use, confirming the use of Galician marbles in Roman times (Gutiérrez Garcia-M. et al., in press). Nevertheless, some objects clearly belonging to lithotype O Incio-2 show an isotopic signature falling near but not within the values given by the quarry samples. Thus, further research (surveying for other extraction points and increasing the number of reference samples) needs to be done to check the representativity of the results so far obtained. 
On the other hand, the exploitation of the quarries is also confirmed despite the lack of clearly ancient extraction evidences on the fronts, consequently establishing the bases of further studies aiming to understand ancient stone industry and strategies. Indeed, the exploitation of local marbles emerges as a key factor in ancient Galicia and among them, $\mathrm{O}$ Incio marble seems to have had a main role. It was basically used for architectural elements especially since Late Roman times, and it reached places as far as $100 \mathrm{~km}$ from the quarry. Thus for the first time, we can confirm that not only a local marble was exploited in the NW but more importantly, that a regional-wide distribution network existed, which significantly changes the previous assumptions about marble industry and use in this far off corner of Hispania.

\section{Acknowledgements}

The authors would like to thank the referees for their insights and contributions to improve the manuscript. A special mention to Mauro Brilli of the Instituto di Geologia Ambientale e Geoingegneria, Consiglio Nazionale delle Ricerche (IGAGCNR), (Roma, Italy) for performing the isotopic analysis, and Angel Ferrero Arias of the Instituto Geológico y Minero de España (IGME) for his contribution on identifying marble outcrops as well as Nadia Cantin, Nino del Solar and Brice Lebrun of the IRAMAT-CRP2A for their help on the XRD, spectrophotometry and graphic representation of the results, respectively. The authors also wish to thank the ecclesiastical authorities and several institutions and museums of Galicia (Servizo de Arqueoloxía, Servizo de Museos, Subdirección Xeral de Conservación e Restauración de Bens Culturais, of the Dirección Xeral de Patrimonio de la Xunta de Galicia; Museo Arqueológico Provincial de Lugo; Museo Arqueológico Provincial de Ourense; Museo Arqueológico e Histórico do Castelo de S. Antón; Museo Diocesano de Tui; Museo das Peregrinacións) for allowing us to access and sampling their collections.

This research was performed within the HAR2011-25011 and HAR2015-65319-P funded by the MICINN-MINECO/ FEDER of the Spanish government, and the project "Lapides et marmora Hispaniae:..." of the LaScArBx (programme funded by the ANR-n $\left.n^{\circ} A N R-10-L A B X-52\right)$.

\section{Bibliography}

Aller J., Bastida F., Brime C., Pérez-Estaún A., 1987. Cleavage and its relation with metamorphic grade in the Cantabrian Zone (Hercynian of North-West Spain). Sciences Géologiques Bulletin, 40: 255-272.

Àlvarez A., Domènech A., Lapuente P., Pitarch À., Royo H., 2009a. Marbles and Stones of Hispania. Exhibition Catalogue. ICAC, Tarragona.

Àlvarez A., García-Entero V., Gutiérrez Garcia-M. A., RodÀ I., 2009b. Tarraco marmor. The Quarrying, Use and Trade of Santa Tecla Stone in Roman Times. ICAC, Tarragona.

Amor Meilán M., 1936. Geografía general del Reino de Galicia. Vol VIII-IX: Lugo. Ed. facs. 1980. La Coruña.

Attanasio D., 2003. Ancient white marbles: analysis and identification by paramagnetic resonance spectroscopy. L'Erma di Bretschneider, Rome.

Attanasio D., Brilli M., Ogle N., 2006. The isotopic signature of Classical Marbles. L'Erma di Bretschneider, Rome.

Attanasio, D., Bruno M., Yavuz A.B., Prochaska W., 2015. A Multi-Method Database of the Black and White Marbles of Göktepe (Aphrodisias) Including Isotopic, EPR, Trace and Petrographic data. Archaeometry, 57: 217-245.

Barbin V., Ramseyer K., Decrouez D., Herb R., 1989. Marbles blancs : caractérisation par cathodoluminescence. ComptesRendus Academie des Sciences Paris, 308/II: 861-866.

Barbin V., Ramseyer K., Decrouez D., Burns S.J., Chamay J., MaIer J.L., 1992. Cathodoluminescence of white marbles: an overview. Archaeometry, 34: 175-183.

Beltrán J., Loza Azuaga M.L., 2003. El mármol de Mijas. Explotación, comercio y uso en época antigua. Museo Histórico Etnológico de Mijas, Mijas.

Beltrán J., Nogales T. (ed.), 2009. Marmora hispana: Explotación y uso de los materiales pétreos en la Hispania Romana. L'Erma di Bretschneider, Rome.

BESSAC J.-C., 2003. L'extraction des pierres de taille et des roches marbrières dans l'Antiquité : les principales stratégies d'exploitation. In L. Poulard, A. Richard (ed.). Marbres en FrancheComté: actes des journées d'étude, Besançon 10-12 juin 1999. Association pour la Promotion et le Dévelopement de l'Inventaire comtois, Besançon, 21-34.

Blanc Ph., 1994. La cathodoluminescence quantitative des marbres blancs. $119^{\circ}$ Cong. Nat. Soc, Hist. Scient., Amiens 1994, Carrières et constructions III: 489-504.

Blanc Ph., 1999. Quantification de la cathodoluminescence des marbres blancs et de leurs mineraux accessoires. In M. Schvoerer (ed.). ASMOSIA IV. Actes de la Conférence Internationale ASMOSIA IV, 9-13 Octobre 1995. Archéomatériaux-Marbres et autres roches. CRPAA-PUB, Bordeaux: 45-54. 
Braemer F., 1986. Répertoire des gisements de pierres ayant exporté leur production à l'époque romaine. In F. Braemer (ed.). Les ressources minérales et l'histoire de leur exploitation. Colloque international tenu dans le cadre du $108^{e}$ Congrès national des Sociétés savantes, Grenoble 5-9 avril 1983, Paris, CTHS, Paris, 287-328.

Boggs S., Krinsley D., 2006. Application of cathodoluminescence imaging to the study of sedimentary rocks. Cambridge Univ. Press, Cambridge.

Canto A.M., 1977-1978. Avances sobre la explotación del mármol en la España romana. Archivo Español de Arqueología, 50-51: 165-189.

Capdevilla R., 1969. Le métamorphisme régional progressif et les granites dans le segment hercynien de Galice Nord orientale (NW de l'Espagne). PhD thesis, Université de Montpellier, France.

Capedri S., Venturelli G., 2004. Accessory minerals as tracers in the provenancing of archaeological marbles used in combination with isotopic and petrographic data. Archaeometry 46/4: 517-536.

Casenave S., Chapoulie R., Villeneuve G., 2003. Cathodoluminescence of synthetic and natural calcite: the effects of manganese and iron on orange emission. Mineralogy and Petrology, 78: 243-253.

Chapoulie R., Robert B., Casenave S., 2016. The cathodoluminescence phenomenon used for the study of ancient ceramics and stones. International Journal on Culture and Heritage at Risk - cities of memory, Edifir Florence, 1.1: 53-72.

Cisneros M., 1988. Mármoles hispanos: su empleo en la España romana. Universidad de Zaragoza, Zaragoza.

Cornide de Folgueira SaAvedra J.A., 1789. Memorias sobre las minas de Galicia y otras producciones del Reino Mineral. Cámara Oficial Minera de Galicia, A Coruña. Facsimile 2006.

Delgado Gómez J., 1987. La crucifixión de la iglesia de Hospital do Incio. Una muestra de arte indígena paleocristiano de Galicia. Artes Gráf. de "La Voz de Galicia”, A Coruña.

García-Entero V. (ed.), 2012. El marmor en Hispania. Explotación, uso y difusión en época romana. UNED, Madrid.

García-Entero V., Vidal S., 2007. Marmora from the Roman site of Carranque (Toledo, Spain). Marmora 3: 53-69.

García-Entero V., Vidal S., 2012. El uso del marmor en el yacimiento de Carranque (Toledo)”. In V. García-Entero (ed.). El marmor en Hispania: explotación, uso y difusión en época romana. Madrid, UNED, 135-153.

Gorgoni C., Lazzarini L., Pallante P., Turi B., 2002. An updated and detailed mineropetrographic and C-O stable isotopic reference database for the main Mediterranean marbles used in Antiquity. In Herrmann J., Herz N., Newman R. (ed.). Proceedings of the Fifth International Conference of the
ASMOSIA (Boston, June 1998). Archetype Publications, London, 115-131.

Gutiérrez Garcia-M. A., Remolà Vallverdú J.A., Tarrats Bou F., 2009. Marbles from the Roman villa of Els Munts (Altafulla, Tarragona, Spain) and their role in the decorative program. Preliminary approximation. In IX ASMOSIA International Conference. Book of Abstracts. ICAC, Tarragona, 196.

Gutiérrez Garcia-M. A., Lapuente P., Rodì I. (ed.) 2012. Interdisciplinary Studies on Ancient Stones. Proceedings of the IX ASMOSIA Conference (Tarragona 2009). ICAC, Tarragona.

Gutiérrez Garcia-M. A., RodÀ I., 2012. El mármol de LuniCarrara en la fachada Mediterránea de Hispania. In S. Keay (ed.). Rome, Portus and the Mediterranean. British School at Rome, London, 293-312.

Gutiérrez Garcia-M. A., Royo Plumed H., González Soutelo S. (in press). New Data on Spanish marbles: the case of Gallaecia (NW Spain). In ASMOSIA XI. Proceedings of the XI International Conference (Split, 18-22 May 2015).

Habermann D., Neuser R.D., Richter K., 1998. Lower limit of $\mathrm{Mn}^{2+}$-activated cathodoluminescence of calcite: state of art. Sediment. Geol. 116: 13-24.

Herz N., 1955. Petrofabrics and classical archaeology. Am. J. Sci., 253: 299-305.

IGME 2002. Hoja y Memoria de la hoja 156 (Monforte de Lemos) del Mapa Geológico de España E. 1:50000 (Serie MAGNA), Instituto Geológico y Minero de Espańa (IGME), Madrid.

Lapuente P., Gimeno M.J., Auqué L.F., Asta M.P., 2005. Parámetros de color de los mármoles "blancos" de Saint-Béat, Alto Garona (Francia), MACLA, 3: 121-122.

Lapuente P., Nogales T., Royo H., Brilli M., 2014. White marble sculptures from the National Museum of Roman Art (Mérida, Spain): sources of local and imported marbles. European Journal of Mineralogy, 26: 333-354.

Lapuente P., Nogales-Basarrate T., Royo H., Brilli M., Savin M.-C. (in press). Grey and greyish banded marbles from the Estremoz Anticline in Lusitania. In ASMOSIA XI. Proceedings of the XI International Conference (Split, 18-22 May 2015).

Lapuente P., Preite Martinez M., Turi B., Blanc Ph., 2002. Characterization of dolomitic marbles from the Malaga Province (Spain). In J. Herrmann, N. Herz, R. Newman (eds.), ASMOSIA $V$, Interdisciplinary Studies on Ancient Stone - Proceedings of the Fifth International Conference of the Association for the Study of Marble and Other Stones in Antiquity (Boston, June 1998). Archetype Publications, London, 152-162.

Lapuente P., Royo H. (in press). Cathodoluminescence for the characterization of ancient marble. Problems and research perspective. Marmora Phrygiae. 
Lapuente P., Turi B., Blanc Ph., 200o. Marbles from Roman Hispania: stable isotope and cathodoluminescence characterization. Applied Geochemistry, 15: 1469-1493.

Lazzarini L., Moschini G., Stievano B.M., 1980. A contribution to the identificaation of Italian, Greek and Anatolian marbles through a petrographical study and the evaluation of the Ca/Sr ratio. Archaeometry, 22: 173-183.

Liñán E., Perejón A., Sdzuy K., 1993. The Lower-Median Cambrian stages and stratotypes from the Iberian Peninsula: a revision. Geological Magazine, 130: 817-833.

Liñán E., Gozalo R., Palacios T., Gámez-Vintaned J.A., Ugidos J.M., Mayoral E. 2002. Cambrian. In Gibbons W., Moreno T. (eds.), The Geology of Spain. The Geological Society London, 17-31.

Lotze F., 1945. Zur Gliderung des Varisciden der Iberischen Meseta. Geotektonische Forschungen, 6: 78-92.

Lotze F., 1958. Zur Stratigraphie des spanischen Kambriums. Geologie, 7: 727-750.

Machel H.G., 1985. Cathodoluminescence in calcite and dolomite and its chemical interpretation. Geosci. Canada, 12: 139-147.

Machel H.G., Mason R.A., Mariano A.N., Mucci A., 1991. Causes and emission of luminescence in calcite and dolomite. In C.E. Barker, O.C. Kopp (eds.). Luminiscence microscopy and spectroscopy: qualitative and quantitative applications. SEPM Short course, 25, Tulsa, 37-57.

Madoz P., 1845-50. Diccionario geográfico-estadístico-histórico de España y sus posesiones de Ultramar. $3^{\mathrm{a}} \mathrm{ed} .16$ vols. Imprenta del Diccionario Geográfico-Estadístico-Histórico de D. Pascual Madoz, Madrid.

Martínez Catalán J.R., 1990. West Asturian-Leonese Zone. Introduction. In R.D. Dallmeyer, E. Martínez García (eds.). Pre-Mesozoic Geology of Iberia. Springer-Verlag, Berlin, 88-89.

Maximino Arias, O.S.B., 1983. El monasterio de Samos durante los ss. XI-XII. Archivos Leoneses, 73: 7-81.

Moens L., Roos P., De Rudder J., De Paepe, Van Hende J., Waelkens M., 1988. A multimethod approach to the identification of white marbles used in antique artefacts. In N. Herz, M. Waelkens (eds.). Classical marble: geochemistry, technology, trade, Kluwer Academic Publishers, Dordrecth/Boston/ London, 243-250.

Ontiveros E., Beltrán J., Taylor R., Rodriguez O., López Aldana P., 2012. Petrography and elemental geochemistry of the Roman quarries of Los Castillejos and Los Covachos (Almadén de la Plata, Seville, Spain). Outcrops and semi-elaborated products. In A. Gutiérrez Garcia-M., P. Lapuente, I. Rodà (ed.). Interdisciplinary Studies on Ancient Stone. Proceedings of the IX ASMOSIA Conference (Tarragona 2009). Institut Català d'Arqueologia Clàssica, Tarragona, 407-418.
Otiña P., 2002. Los materiales lapídeos de la villa de Els Munts (Altafulla). Butlletí Arqueològic (Reial Societat Arqueològica de Tarragona), V (24): 111-130.

Otiña P., 2003. La importación del mármol en la villa romana de Els Munts (Altafulla, Tarragona). Anales de Arqueología Cordobesa, 13-14: 147-166.

Pensabene P., Gasparini E. (eds.), 2015. Proceedings of the Tenth International Conference of ASMOSIA, Interdisciplinary Studies on Ancient Stones. L'Erma di Bretschneider, Rome.

Pérez C., Reyes O., Rodì I., Àlvarez A., Gutiérrez Garcia-M. A., Domènech A., Royo H., 2012. Use of marmora in the ornamental program of Las Pizarras Roman site (ancient Cauca, Segovia, Spain). In A. Gutiérrez Garcia-M., P. Lapuente, I. Rodà (eds.). Interdisciplinary Studies on Ancient Stones. Proceedings of the IX ASMOSIA Conference (Tarragona 2009). ICAC, Tarragona, 151-160.

Pérez-Estaún A., Bastida F., Martínez Catalán J.R., Gutiérrez Marco J.C., Marcos A., Pulgar J.A., 1990. West Asturian-Leonese Zone. Stratigraphy, In R.D. Dallmeyer, E. Martínez García (eds.). Pre-Mesozoic Geology of Iberia, Berlin, Springer-Verlag, 92-102.

Rodríguez Colmenero A., 1993. Historia del arte romano en Galicia. In F. Rodríguez Iglesia (dir.) Galicia Arte, IX. Hércules ediciones, A Coruña, 237-501.

Royo H. 2016. Mármoles de la Cordillera Pirenaica: afloramientos norpirenaicos y asociados al "Nappe des Marbres". Caracterización y uso en época romana. $\mathrm{PhD}$ thesis, Universidad de Zaragoza, Zaragoza.

Royo H., Lapuente P., Cuchí J.A., Brilli M., Savin M.-C., (in press). Updated characterization of white Saint-Béat marble. Parameters of its discrimination from Classical marbles. In Proceedings of the XI ASMOSIA Conference (Split, may 2015).

TAYLOR R., 2015. Las canteras romanas de mármol de Almadén de la Plata (Sevilla, España): un análisis arqueológico. PhD thesis, Universidad de Sevilla, Sevilla.

Valero M.A., Gutiérrez García-M. A., RodÀ I., 2015. First preliminary results on the marmora of the Late Roman villa of Noheda (Cuenca, Spain). In P. Pensabene, E. Gasparini (eds.). Proceedings of the Tenth International Conference of ASMOSIA, Interdisciplinary Studies on Ancient Stones, L'Erma di Bretschneider, Rome, 393-402.

Vidal S., García-Entero V., 2015. The use of Estremoz marble in Late Antique Sculpture of Hispania: new data from the petrographic and cathodoluminescence analyses. In P. Pensabene, E. Gasparini (eds.). Proceedings of the Tenth International Conference of ASMOSIA, Interdisciplinary Studies on Ancient Stones. L'Erma di Bretschneider, Rome, 413-420.

WeIss L.E., 1954. Fabric analysis of some Greek marbles and its applications to archaeology. Am. J.Sci., 252: 641-662. 


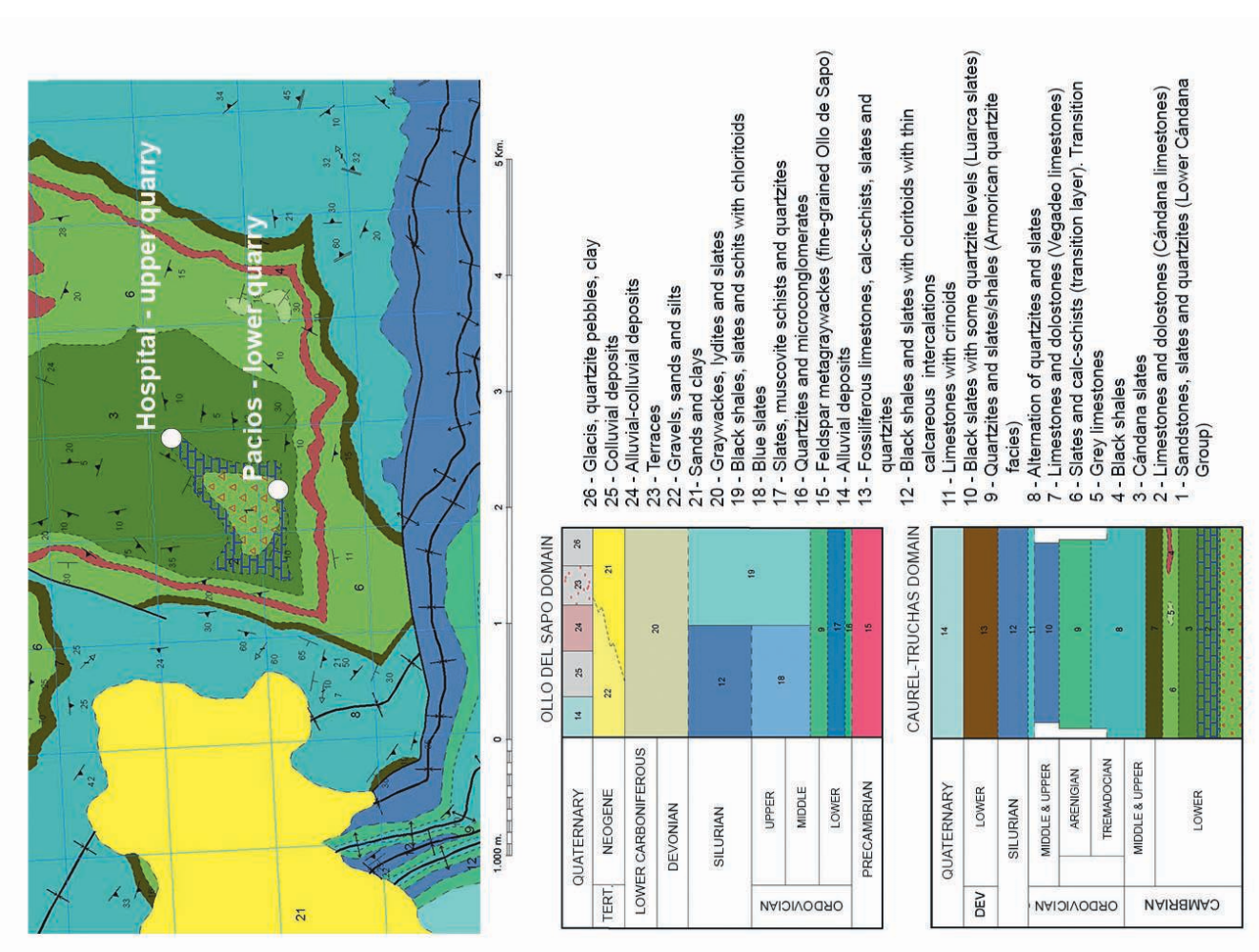

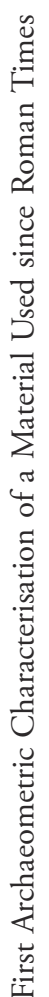

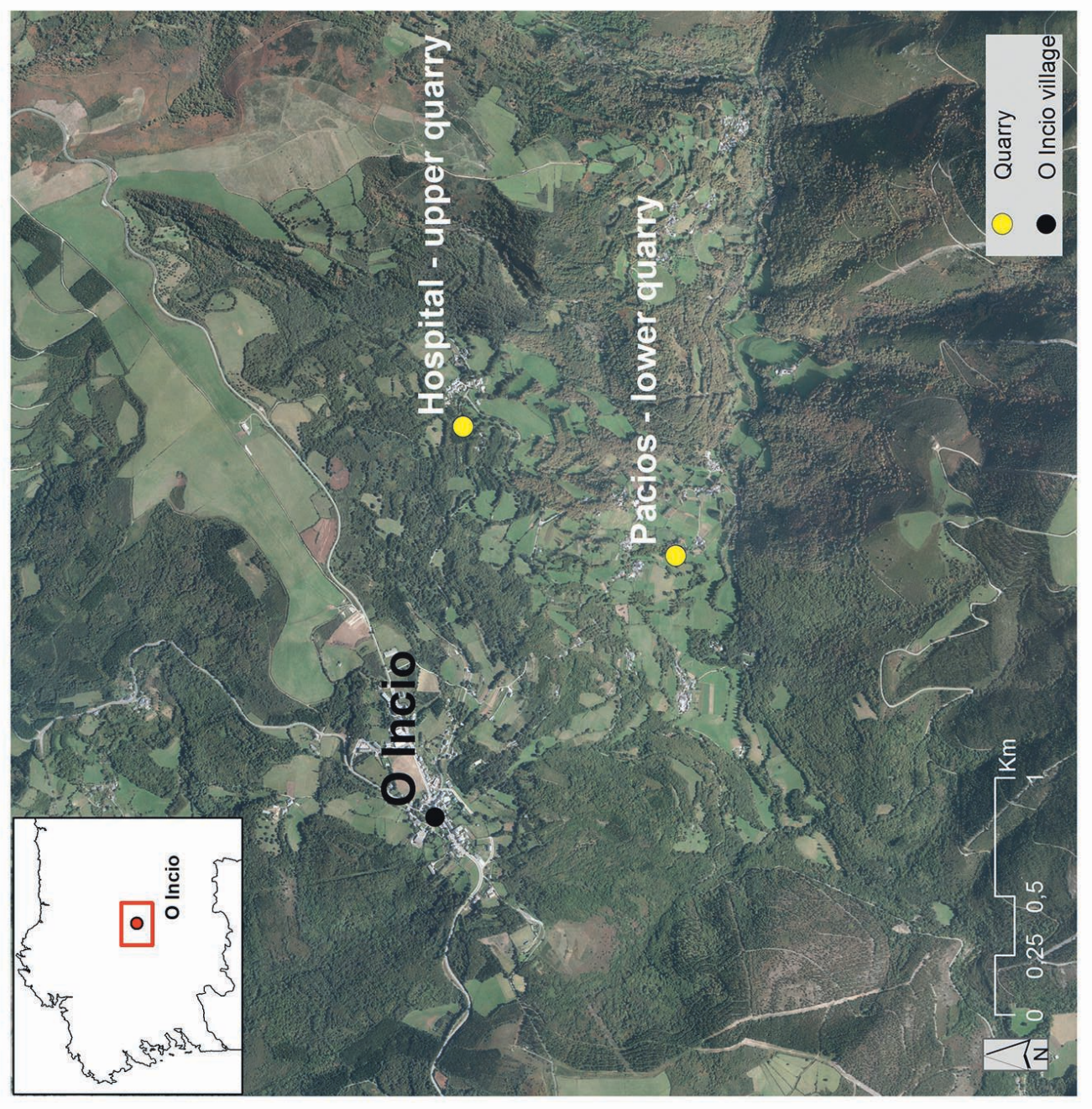

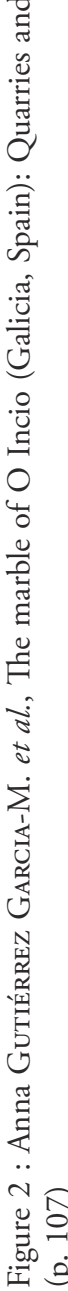




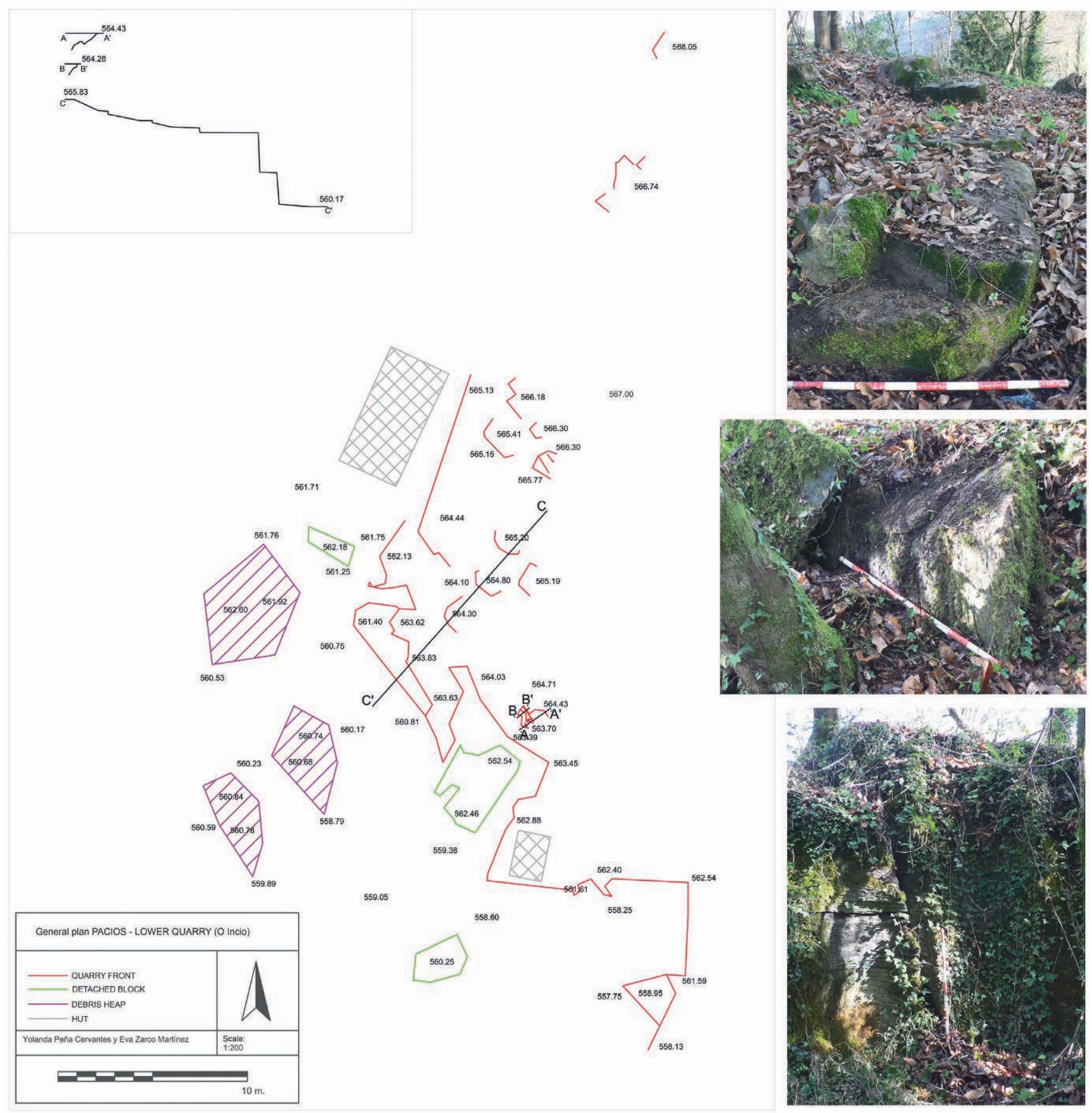

Figure 3 : Anna Gutiérrez Garcia-M. et al., The marble of O Incio (Galicia, Spain): Quarries and First Archaeometric Characterisation of a Material Used since Roman Times (p. 108) 


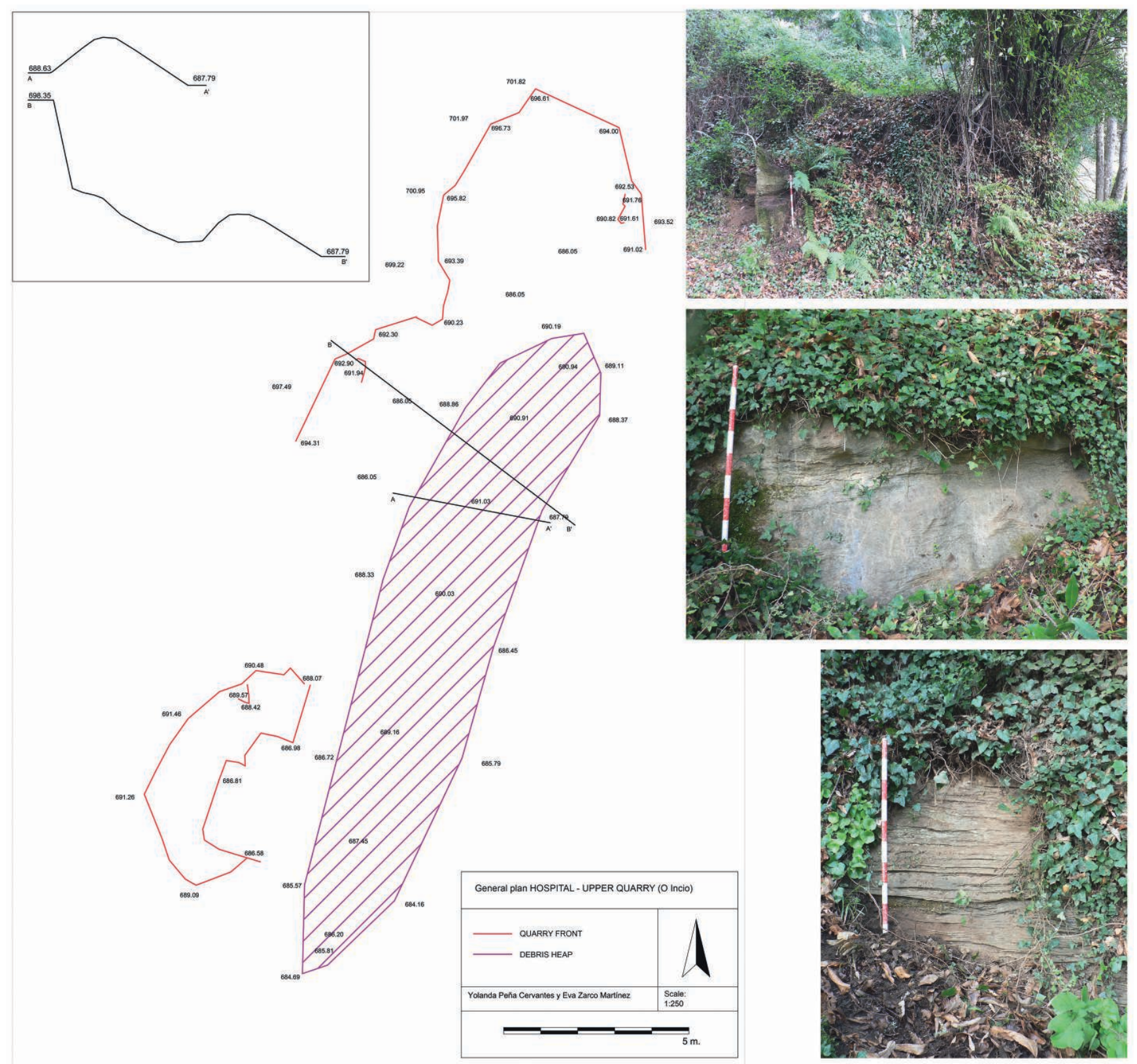

Figure 4 : Anna Gutiérrez Garcia-M. et al., The marble of O Incio (Galicia, Spain): Quarries and First Archaeometric Characterisation of a Material Used since Roman Times (p. 109)

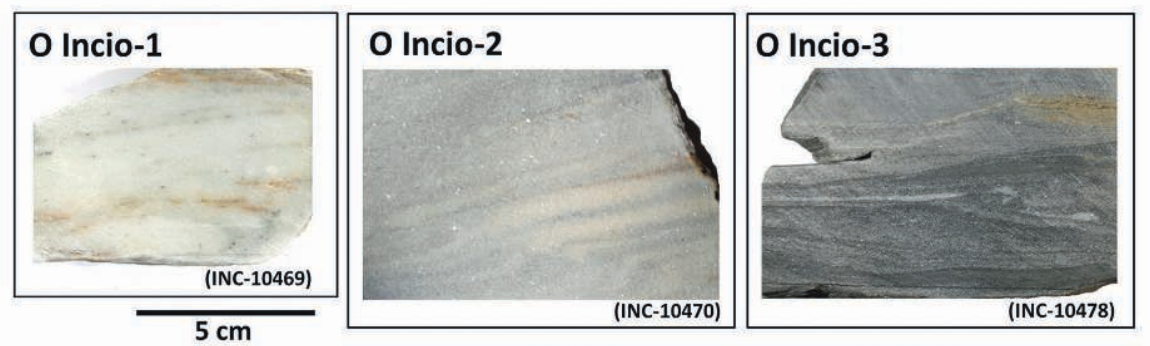

Figure 5 : Anna Gutiérrez Garcia-M. et al., The marble of O Incio (Galicia, Spain): Quarries and First Archaeometric Characterisation of a Material Used since Roman Times (p. 110) 

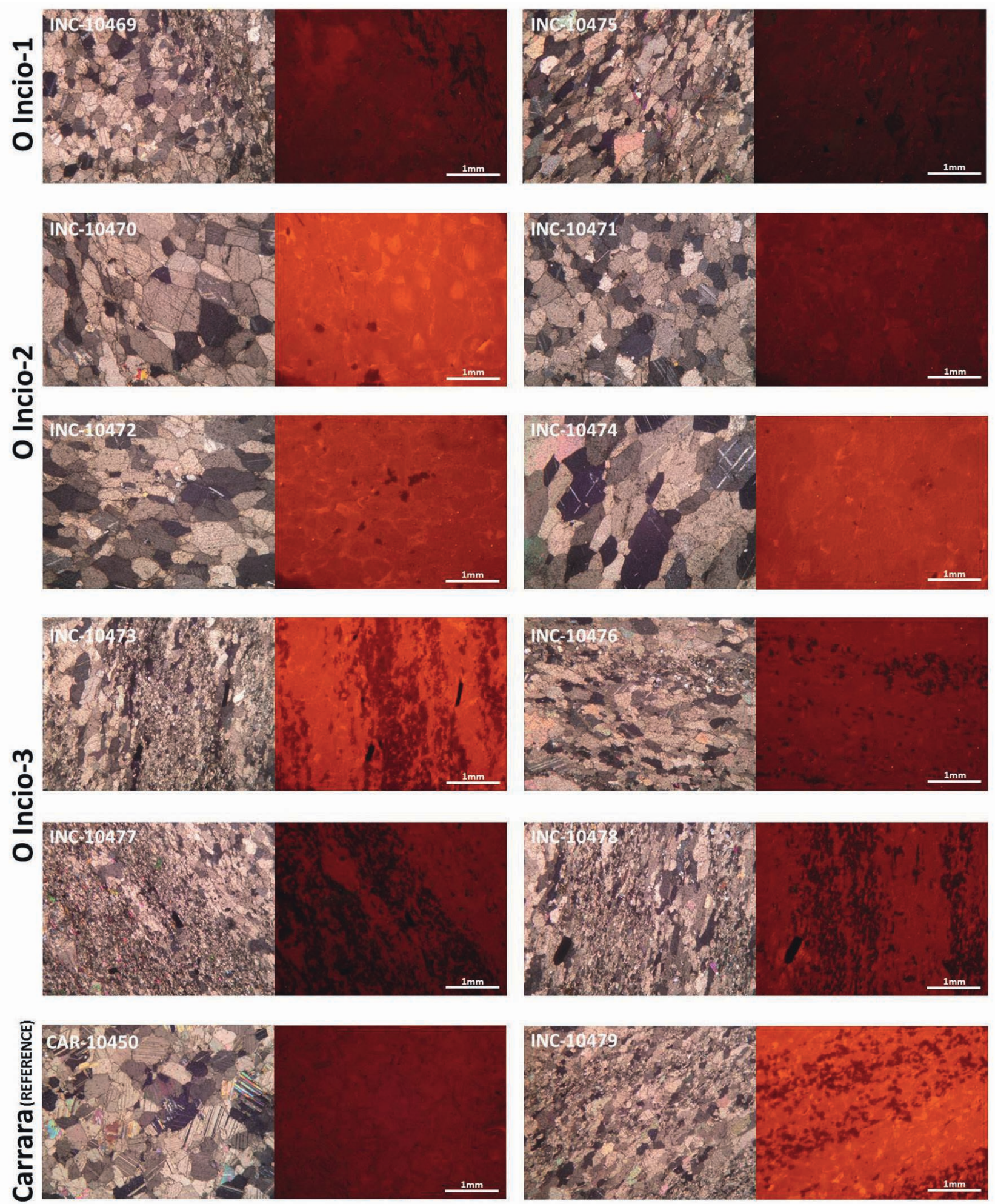

Figure 7 : Anna Gutiérrez Garcia-M. et al., The marble of O Incio (Galicia, Spain): Quarries and First Archaeometric Characterisation of a Material Used since Roman Times (p. 113) 